\title{
Role of Cytokinins in Senescence, Antioxidant Defence and Photosynthesis
}

\author{
Martin Hönig ${ }^{1,2,+}$, Lucie Plíhalová ${ }^{1,2, *,+}$ (D) Alexandra Husičková ${ }^{3} \mathbb{C}$, Jaroslav Nisler $^{1,2}$ and \\ Karel Doležal ${ }^{1,2}$ \\ 1 Department of Chemical Biology and Genetics, Centre of the Region Haná for Biotechnological and \\ Agricultural Research, Faculty of Science, Palacký University, Šlechtitelů 27, CZ-783 71 Olomouc, \\ Czech Republic; martin.honig@upol.cz (M.H.); jaroslav.nisler@gmail.com (J.N.); karel.dolezal@upol.cz (K.D.) \\ 2 Laboratory of Growth Regulators, Centre of the Region Haná for Biotechnological and Agricultural \\ Research, Palacký University \& Institute of Experimental Botany ASCR, Šlechtitelů 27, CZ-783 71 Olomouc, \\ Czech Republic \\ 3 Department of Biophysics, Centre of the Region Haná for Biotechnological and Agricultural Research, \\ Faculty of Science, Palacký University, Šlechtitelů 27, CZ-783 71 Olomouc, Czech Republic; \\ alexandra.husickova@upol.cz \\ * Correspondence: lucie.plihalova@upol.cz \\ $\dagger$ These authors contributed equally to this work.
}

Received: 24 October 2018; Accepted: 12 December 2018; Published: 14 December 2018

\begin{abstract}
Cytokinins modulate a number of important developmental processes, including the last phase of leaf development, known as senescence, which is associated with chlorophyll breakdown, photosynthetic apparatus disintegration and oxidative damage. There is ample evidence that cytokinins can slow down all these senescence-accompanying changes. Here, we review relationships between the various mechanisms of action of these regulatory molecules. We highlight their connection to photosynthesis, the pivotal process that generates assimilates, however may also lead to oxidative damage. Thus, we also focus on cytokinin induction of protective responses against oxidative damage. Activation of antioxidative enzymes in senescing tissues is described as well as changes in the levels of naturally occurring antioxidative compounds, such as phenolic acids and flavonoids, in plant explants. The main goal of this review is to show how the biological activities of cytokinins may be related to their chemical structure. New links between molecular aspects of natural cytokinins and their synthetic derivatives with antisenescent properties are described. Structural motifs in cytokinin molecules that may explain why these molecules play such a significant regulatory role are outlined.
\end{abstract}

Keywords: cytokinin; derivative; antisenescent; antioxidant; structure and activity relationship; genes; antioxidant enzymes; photosynthesis; plant defence

\section{Introduction}

Naturally occurring cytokinins (CKs) are purine based plant growth regulators that influence almost all of the developmental stages of plant life, e.g., development of vasculature, differentiation of embryonic cells, maintenance of meristematic cells, shoot formation and leaf senescence delay. CKs were first discovered as substances that promoted cell division in tissue cultures in the presence of auxin [1]. Naturally occurring CKs are purine based molecules that are substituted at the $\mathrm{C} 6$ atom either by an isoprene side chain (ISCKs) or aromatic core (ARCKs). ISCKs are represented by naturally occurring 6-(E)-4-hydroxy-3-methylbut-2-enylaminopurine (trans-zeatin, $t Z$ ), 6-(Z)-4-hydroxy-3-methylbut-2-enylaminopurine (cis-zeatin, $c Z$ ) and 6-(2-isopentenylamino)purine (iP). ARCKs include 6-benzylaminopurine (BAP), 6-furfurylaminopurine (kinetin, Kin) and $o-, m$ - and 
p-hydroxylated or methoxylated derivatives of BAP, called topolins [2]. Although BAP and Kin are not traditionally considered as naturally occurring CKs, exogenous treatment with them showed such strong effects on plant tissues that these molecules were often used experimentally and formed the basis of the first generation of synthetic ARCKs [3]. Nucleosides, nucleotides and other sugar conjugates of many CKs have been found in plants, and metabolic networks exist for their interconversions [1]. Moreover, the presence of a purine moiety enables a number of possible modifications, including substitution at the $\mathrm{C} 2, \mathrm{~N} 1, \mathrm{~N} 3, \mathrm{C} 6, \mathrm{~N} 7$ or N9 atoms of the original purine heterocycle [3]. The family of $\mathrm{CK}$ compounds includes a large array of natural and synthetic purine and phenylurea derivatives. The most effective phenylurea CK is thidiazuron (TDZ) [4]. The majority of these compounds are not considered as naturally occurring, however they possess significant CK activity [1]. The action of CKs is often influenced by interaction with other hormones, e.g., auxins or ethylene [4]. One of the most valued features of $\mathrm{CK}$ action and the focus of this review is regulation of senescence, especially senescence delay, owing to the potential for economic benefits [5-8]. Leaf senescence is the final step in leaf development and is often accompanied by colour changes from green to yellow or brown [9]. Leaf yellowing is not only age dependent, it can also be induced by a number of other factors, including biotic stress, mechanical damage, harvesting and environmental stress [10]. Leaf senescence seems to be directly related to a decrease in CK concentration and activity. Generally, CKs are more effective when applied to detached plant organs [5,11], however they can also delay the senescence of attached leaves. CKs are also effective in delaying the breakdown of chlorophyll, suggesting that they may play a role in maintaining the photosynthetic apparatus of plants [5]. Many of the biological activities of CKs in plants can be explained by their involvement in cellular oxidative stress, and the antioxidant capacity of these molecules has already been described [12]. Leaf senescence is accompanied by a gradual decline in antioxidants and an increase in reactive oxygen species (ROS) and content of malondialdehyde (a decomposition product of lipid peroxidation) in certain plants [13,14]. Increased lipid peroxidation and $\mathrm{H}_{2} \mathrm{O}_{2}$ formation have been demonstrated along with a decline in the activities of enzymes, such as catalase (CAT) and ascorbate peroxidase (APX), as well as glutathione (GSH) content during senescence in pea and Arabidopsis leaves [13,15].

Regulation of the onset of senescence is important owing to its impact on dynamic nutrient relocations during the degradation of cellular components [9]. Leaf senescence can be regulated in a number of ways that include ethylene production and expression of senescence associated genes (SAGs). Important roles are played by antioxidant enzymes, such as CAT, APX and superoxide dismutase (SOD), and compounds related to oxidative stress, such as phenolic acids, flavonoids and $\mathrm{H}_{2} \mathrm{O}_{2}$. Changes in chlorophyll are inseparably linked to photosynthesis. Exogenous treatment with $\mathrm{CKs}$ and their derivatives or genetic engineering to create plants that overproduce CKs can lead to significant senescence delay. In this review, we focus on the main mechanisms of action by which CKs and their derivatives delay leaf senescence.

\section{Antisenescent and Antioxidant Activity of Natural Cytokinins (CKs), Kinetin (Kin) and 6-Benzylaminopurine (BAP)}

The first evidence for the antisenescent activity of CKs was provided by Richmond and Lang [16] in an experiment testing exogenous application of Kin on excised leaves of cocklebur plants (Xanthium pensylvanicum) and tobacco. The results showed that this led to re-greening in yellowing tobacco leaves, however not in Xantium pensylvanicum [17]. The need to measure the ability of CKs in retarding chlorophyll degradation in various plant tissues prompted the development of several different senescence bioassays. CKs can be applied as droplets on leaves or by floating leaves (or their parts) on a CK solution or by inserting the base of a detached leaf into a CK solution [18]. The latter method has been optimized with wheat leaf segments [19], known as the wheat leaf senescence assay (WLSA), and is widely used to assess the antisenescence properties of CKs. Briefly, a tip section of a seven-day-old wheat leaf is inserted into a solution of CK and is placed in the dark for five days. 
Afterwards, any chlorophyll remaining in the leaf tips is extracted by $80 \%$ ethanol and its content is determined spectrophotometrically at $665 \mathrm{~nm}$ [19].

Comparison of the antisenescent activity of different CK free bases in the WLSA performed according to protocol described by Holub et al. showed that $t Z$ clearly had the highest activity, followed by 6-(3-hydroxybenzylamino)purine (meta-topolin, $m \mathrm{~T})$, of which its activity was only marginally lower than that of $t Z$ [19]. BAP and Kin had similar activity in the WLSA, however both compounds were less active than $t Z$ and $m \mathrm{~T}$ [19]. In contrast, 6-(2-hydroxybenzylamino)purine (ortho-topolin, $o \mathrm{~T}$ ), cis-zeatin and iP were considered as CKs with low or no antisenescent effect [19-21]. The activities of $t Z, c Z, m \mathrm{~T}$, BAP and Kin in the WLSA are compared in Figure 1A. Holub et al. [19] further showed that 9-ribosides of $t Z, B A P, m \mathrm{~T}$ and $o \mathrm{~T}$ were more active than their free bases [19]. In the case of $t \mathrm{Z}$ and trans-zeatin riboside ( $t Z R)$, this was in accord with results of Spíchal et al. [22] and Kim et al. [23]. Both $t Z$ and $t Z R$ strongly activated the Arabidopsis CK receptor AHK3, which was shown by Kim et al. [23], to play a crucial role in CK-mediated leaf longevity through phosphorylation of the CK response regulator ARR2. Conversely, benzylaminopurine riboside (BAPR) and $m$ TR did not activate the AHK3 receptor [22], however they were found to be active in the WLSA [19]. Doležal et al. [24] suggested that ARCKs, especially $o-, m$-methoxy and halogeno derivatives of BAP, may protect against the degradation of the photosynthetic apparatus. This was based on findings that substituted ARCKs had antisenescent activities similar to or higher than those of $t Z$ yet activated Arabidopsis CK receptors AHK3 and CRE1/AHK4 only weakly [22,24].

Better understanding of CK involvement in plant senescence was provided by analyses of CK concentration levels through plant development and tissues. These studies revealed an inverse relationship between CK levels and the progression of senescence in a variety of tissue and plant species $[5,25]$. The importance of naturally occurring ISCK sugar conjugates, dihydrozeatin riboside (DHZR) and zeatin riboside (ZR), in xylem sap during plant senescence was identified in experiments on soybean [26]. CK levels in the xylem sap of soybean (Glycine max) decreased rapidly with the onset of leaf senescence [26]. Reduction in endogenous CKs (zeatin (Z), dihydrozeatin (DHZ), ZR, DHZR) was also observed in tobacco leaves during the progression of leaf senescence [27]. However, in exogenous CK application experiments, it was unclear how much of the hormone was actually transported to and taken up by the plant tissues. Moreover, these factors may differ in different species or under different experimental conditions [25]. Podlešáková et al. published a study on the acropetal transport of 6-(3-methoxybenzylamino)purine (meta-methoxytopolin, $m \mathrm{MT})$, 9-(4-chlorobutyl) and 9-(tetrahydropyran-2-yl, THP) derivatives of $m \mathrm{MT}$. It was shown that the derivatives allowed the gradual release of the active base and had a significant impact on the distribution and amount of endogenous ISCK in various plant tissues [28]. Although a relationship between CK levels and senescence progression was found, the regulatory role of CKs in plant senescence was clarified using transgenic plants. Cloning of the Agrobacterium IPT (isopentenyl transferase) gene encoding a CK producing enzyme provided a way to genetically engineer plants in which endogenous levels of these hormones could be increased [6]. The effect of CK treatment on these genetically altered plants is discussed in the text below.

Since naturally occurring CKs contain heterocycles in their structure and are able to regulate leaf senescence, questions were raised about their possible antioxidant activity. Increased levels of $\mathrm{H}_{2} \mathrm{O}_{2}$, lipid peroxidation and membrane leakiness were observed during leaf senescence in tobacco, rice, pea, sunflower and barley [13,29-33]. External application of BAP increased the activity of CAT and APX enzymes and reduced the level of $\mathrm{H}_{2} \mathrm{O}_{2}$ during dark senescence of wheat leaves. It was suggested that externally applied CKs may protect the cell membranes and photosynthesis system from oxidative damage during the delay of senescence in the dark [34,35]. However, in dexamethasone-inducible IPT transgenic tobacco plants with increased levels of endogenous CKs, higher concentrations of $\mathrm{H}_{2} \mathrm{O}_{2}$ were detected, especially in chloroplasts. Moreover, the increased levels of $\mathrm{H}_{2} \mathrm{O}_{2}$ resulted into elevated lipid peroxidation [36]. It was shown by the analysis of the end-product of lipid peroxidation, 
malondialdehyde (MDA), that lipid peroxidation is not associated with leaf senescence in stay-green tobacco plants [14].
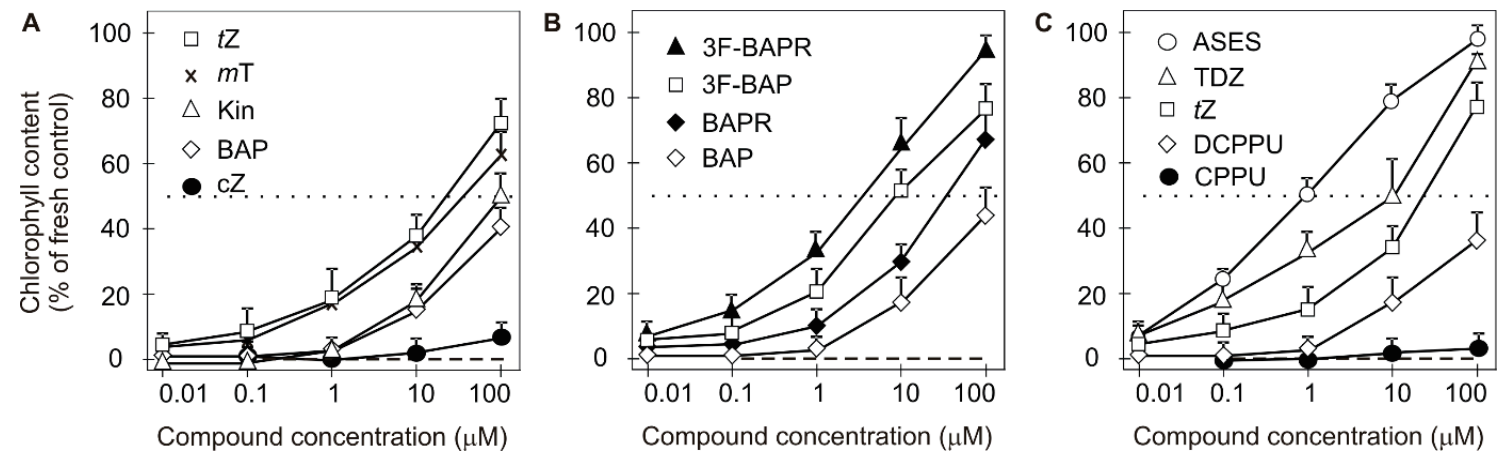

Figure 1. Evaluation of the biological activity of (A) classical cytokinins, (B) 3-fluoro derivatives of BAP and BAPR and $(\mathbf{C})$ urea based cytokinins in the wheat leaf senescence assay performed in the dark (according to [19]). The dotted line indicates where the chlorophyll content in the leaves is $50 \%$ of that in fresh control leaves, while $100 \%$ represents the chlorophyll content in fresh control leaves. Dashed lines indicate values for the control treatment (DMSO control) with no added compound. Error bars show the S.D. of the mean for four replicate determinations.

\section{Antisenescent and Antioxidant Activity of C2, C8 and N9 Purine-Based CK Derivatives}

Since ISCKs and ARCKs appear to be crucial to senescence regulation, a number of their derivatives have been prepared to study the structure and activity relationship of these processes. In 1989, Zhang et al. measured the antisenescent activity of nine substituted CK derivatives using soybean leaf discs. Of the 14 BAP derivatives tested, including 9-alanine, 9-tetrahydropyranyl and 9-tetrahydrofuranyl, the last two derivatives were found to be the most active in the bioassay due to their great stability and ability to gradually release free BAP [37]. In the same year, another series of 9-substituted derivatives of four common naturally occurring CKs were tested in the soybean callus assay. Specifically, 9-(2-Carboxyethyl), 9-(2-carbo-t-butoxyethyl) and 9-(2-nitroethyl) derivatives of $t Z, c Z, D H Z$ and iP all reduced the biological activity of the parent compounds [38]. Another 33 6-BAP-9-tetrahydropyranyl (THP) and 9-tetrahydrofuranyl (THF) derivatives with variously positioned hydroxyl- and methoxy-functional groups on the benzyl ring were prepared by Szüčová et al. [39]. The majority of the prepared derivatives showed higher antisenescent activity than the standard BAP or parent CKs (exceptions were derivatives substituted in $p$ - positions or derivatives with a blocked N6-H atom) [39-41]. In contrast, derivatives shorter by a $\mathrm{CH}_{2}$ group, i.e., 6-anilinoaminopurine derivatives, prepared by Zatloukal et al. were shown to be inactive in the WLSA [42]. Eight Kin derivatives were prepared by the addition of various halogenoalkyls, ethoxyethyl, carboxyl or THF groups to the N9 atom of the purine moiety. Some of these derivatives, especially those bearing THF, ethoxyethyl and chloroethyl, were highly active in the WLSA (reaching $110-131 \%$ of the original Kin) [34]. Moreover, compounds that were active in the senescence bioassay significantly reduced peroxidation of membrane lipids under dark conditions [34].

In addition to N9-substitution, a number of BAP derivatives were prepared by Doležal et al. with substitutions (halogen(s), methyl or methoxy group(s)) in various positions on the N6-benzyl ring [24]. Among them, 3-fluoro-BAP (3F-BAP) exhibited the highest antisenescent activity in the WLSA (Figure 1B). Some derivatives also possessed increased antisenescent activity compared to BAP (for details, see [24]). One year later, Doležal et al. published similar work on the preparation and testing of BAPR derivatives [43]. Unsurprisingly, BAPRs were found to be more effective than the corresponding BAPs (Figure 1B). Specifically, 3F-BAPR was the most active compound in the WLSA, with antisenescent activity up to $220 \%$ of that of BAP [43] (Figure 1B). Vylićilová et al. [44] prepared 14 halogenated derivatives of BAPR by the addition of chlorine at the C2 atom of purine. The compounds exhibited increased antisenescence activity in the WLSA compared 
to BAPs, however lower activity than BAPR derivatives. In other words, chlorine substitution at $\mathrm{C} 2$ decreased the antisenescent activity of BAPR and counteracted the positive activity of ribose. The antisenescent activity of 2-chloro-6-(3-fluorobenzylamino)purine-9-riboside (2cl-3F-BAPR) is thus similar to the activity of 3F-BAP. For clarity, we have again compared the antisenescence activity of BAP, BAPR, 3F-BAP a and 3F-BAPR in one WLSA according to Holub et al. [19] (Figure 1B). In addition, Vylíćilová et al. further showed that the introduction of chlorine to the $\mathrm{C} 2$ position of the purine moiety dramatically decreased the toxicity of several toxic previously prepared BAPs and BAPRs $[24,43,44]$. The antisenescent activity of 2-chloro-6-(3-fluororbenzylamino)purine-9-riboside (2Cl-3F-BAPR) was similar to the activity of 3F-BAP. However, this study of Vylíćilová et al. was the first to uncover possible targets of the BAPR derivatives in the inhibition of chlorophyll degradation [44]. Genome-wide expression profiling showed that the synthetic halogenated derivatives of BAPR affected transcription of a unique combination of genes coding for components of the photosystem II (PSII) reaction centre, light-harvesting complex II (LHCII) and oxygen-evolving complex, as well as several stress factors responsible for regulating photosynthesis and chlorophyll degradation [44].

More recently, 11 Kin derivatives were prepared and tested in the WLSA. The presence of an oxygen atom in the furan ring was shown to be a critical structural motif for slowing the breakdown of chlorophyll in the WLSA. Replacement of the oxygen atom by sulphur or carbon resulted in decreased antisenescent activity. On the other hand, saturation of the furan ring did not have such a negative impact on the antisenescent activity. Moreover, 9-THF substitution had no effect or slightly improved the antisenescent activity of 6-(tetrahydrofuran-2-ylmethyl)aminopurine, Kin and 6-(thiophen-2-ylmethyl)aminopurine (thiokinetin). The addition of chlorine at the $\mathrm{C} 2$ atom of purine moiety lowered or completely reduced the antisenescent activity of the prepared compounds. Furthermore, the prolongation of the C-bridge carrying the N6-substituent of 6-(2-thiophen-2-ylethyl)aminopurine led to the complete loss of the antisenescent activity in the WLSA [45].

Synthetic CK analogues, particularly 6-alkynyl and 6-alkenylaminopurines, some of which were also substituted at the N9 atom of the purine moiety, have been tested for their antioxidant activity as potential diphenylpicrylhydrazyl (DPPH) scavengers and as inhibitors of 15-lipoxygenase enzyme, together with naturally occurring CKs BAP, Kin and $t Z$ [46]. Whereas naturally occurring CKs were unable to scavenge DPPH, some of the prepared compounds were significantly more active than BAP, Kin and $t Z$. The most active compounds were 6-(3-thienylethenyl)purine, with $18 \%$ scavenging activity after $15 \mathrm{~min}$, however also derivatives incorporating 2-furyl in their structure [46].

Substitution of the $\mathrm{C} 6$ atom of the purine moiety seems to be crucial for the antisenescent properties of the prepared derivatives. A unique example of an inactive CK is isopentenylaminopurine (iP). Neither iP nor its derivatives are active in the WLSA. To test this, a series of N6-(3-methylbut-2-en-1yl)amino)purine (iP) derivatives substituted at the N9 atom of the purine moiety was prepared in 2011 [21]. As expected, none of these compounds were active in the WLSA, although the prepared compounds were evaluated as active CKs in other CK bioassays [21].

Recently, another 58 CK derivatives substituted at the C8 atom of the purine moiety, 27 of which were 9-tetrahydropyranyl precursors of CKs, were published by Zahajská et al. [47]. The introduction of C8 substitution led to a decrease or even the complete loss of antisenescent activity in the majority of compounds compared to the corresponding free bases. However, 6-benzylamino-7,9-dihydro-8H-purin-8-one (8-oxo-BAP) exhibited higher activity than BAP by $34 \%$. Concurrently, among Kin derivatives, methoxy- and 2-hydroxyethyloxy-C8 substituents did not decrease the activity of Kin. With some exceptions, compounds with a 9-(tetrahydropyran-2-yl) protective group exhibited even lower activity in the WLSA than their THF deprotected analogues [47]. This observation is in contrast to previous studies, in which the introduction of 9-THP or 9-THF protective groups was found to not decrease the antisenescent activity of the corresponding free bases $[37,40,45,48]$.

According to the above, the crux of the antisenescent activity of CKs appears to be appropriate substitution at the N6 atom. Concurrently, the N6-H hydrogen must stay unsubstituted. Substituents at 
nearby atoms, such as N6, must contain an oxygen atom incorporated into oxo-, hydroxyl or methoxy groups and/or halogen atoms, such as fluorine or chlorine. Further, $t Z$, Kin and topolins are typical examples of CKs shown to be very active in antisenescent bioassays. Substitution at C8 drastically reduces the antisenescent properties of nearly all, even the active $\mathrm{CKs}$, with one exception: compounds substituted by oxygen at C8 remain active. Substituents at the N9 atom can vary, however they do not normally affect the antisenescent properties much if the N6 substitution is "antisenescent", with the exception of ribosides, which in some cases are more active. Questions arise concerning whether other sugars at the N9-position may have a similar or even better effect. The structural trends described above show that the antisenescent effects are probably connected with the presence of electronegative atoms, oxygen and halogens, which are close to the N6 and/or N9 atoms of purine. Both the N6H and N7H hydrogen atoms are present and "free to operate" in all active compounds. The second condition is the presence of $-\mathrm{O}-,-\mathrm{OH},-\mathrm{X}$ or $-\mathrm{OCH}_{3}$ substitutions close to this area. These two factors can lead to the concentration of electron density and increase of antisenescent activity in such compounds. The electron density enhancement at these strategic atoms is most probably responsible for the antisenescent effects.

Based on the available literature and a large amount of data, it is evident that the antisenescent properties of some CK derivatives are not directly associated with their CK activity. Moreover, iP and its derivatives are active CKs, however they are inactive in the WLSA [21,47]. Conversely, some derivatives of BAP, BAPR, 9-THF (THP)-BAP and Kin exhibit low CK activity at the receptor level, lower or average activity in other CK bioassays, however increased antisenescence activity $[34,39,43]$.

An example of such phenomena-the presence of an oxygen containing group and lack of relation of CK activity to the antisenescent activity-was provided recently by Nisler et al. [49]. They showed that urea derived compounds are extremely active in the WLSA (Figure 1C) if they contain a methoxy group (a compound called ASES), hydroxyl or other electron-rich groups. Interestingly, the compounds also needed to have a second NH not substituted (like the N6H in purines) to be active in the WLSA. It was also shown that the compounds exhibited none or very low CK activity in almost all CK assays. Analysis of chloroplast membrane proteins showed that one way in which these urea derivatives delay senescence is by inhibition of photosystem II degradation [49]. This study agrees with that of Vyličilová [44] and, at the protein level, supports and complements results at the transcriptional level.

Finally, it is worth noting that according to the literature, CKs (as well as other compounds with antisenescent properties) inhibit chlorophyll degradation by several mechanisms that may act synergistically. Some have been identified and well described, whereas others await discovery.

\section{Antisenescent Activity of Urea Based CKs and Their Derivatives}

Urea based compounds represent another class of highly active synthetic CKs. The best known are TDZ, $N$-(2-chloropyridin-4-yl)- $N^{\prime}$-phenylurea (phenylurea, CPPU) and N-(2,6-dichloro-pyridin4 -yl)- $N^{\prime}$-phenylurea (DCPPU). So far, TDZ appears to be the best representative of the synthetic CKs in terms of CK receptor activation [22], promotion of CK dependent callus growth $[50,51]$ and, most importantly, inhibition of plant senescence [52-55]. In most CK bioassays, including the WLSA, TDZ exhibits even higher activity than $t Z[22,49])$. This may be due to a number of reasons, e.g., TDZ exhibits strong CK activities in several bioassays, however in contrast to $t Z$, cannot be degraded by cytokinin oxidase dehydrogenase (CKX, a key enzyme involved in CK degradation in plants [56,57]). TDZ cannot be deactivated by $O$-glucosylation and can maintain a higher content of endogenous CKs in plant tissue by inhibiting the function of CKX [58-60]. Owing to its high CK and particularly antisenescence activity, TDZ has been extensively studied and used to prolong the life of cut flowers [55]. In this field, no other substance has received as much attention as TDZ.

Several mechanisms for explaining how TDZ delays plant senescence have been shown in studies of various plant species [61]. In Matthiola incana cut flowers, TDZ reduced stress responses by inhibiting abscisic acid production, resulting in a higher content of chlorophyll and carotenoids [61] in stem leaves. Like ethylene, abscisic acid promotes senescence [62], occurs as a response to stress and is considered 
to be a marker of stress-induced senescence [63]. It was further shown that in Pelargonium cuttings, TDZ induced strong expression of PhETR1 (a negative acting ethylene receptor gene), thus decreasing the sensitivity of Pelargonium leaves to ethylene [64]. Ethylene is known to accelerate and accompany senescence $[65,66]$. In Pelargonium zonale, TDZ was shown to increase the levels of APX and SOD, which are enzymes of the antioxidant defence system [67]. Another complex study was carried out on stems and florets of cut Chrysanthemum morifolium plants. Both BAP and TDZ were found to increase the activity of antioxidant enzymes SOD and peroxidase (POD), reduce production of $\mathrm{H}_{2} \mathrm{O}_{2}$, minimize lipid peroxidation and maintain high levels of sugars in cut stems and florets. Treated plants also showed increased water uptake and prolonged the post-harvest quality of florets and leaves. In this study, TDZ again exhibited higher activity and in lower concentrations than BAP [68]. The antisenescent activity of CPPU, DCPPU, TDZ and ASES was compared in one WLSA (Figure 1C) according to Holub et al. [19].

To conclude, from the literature reviewed, it appears that TDZ delays senescence in plants by the same mechanisms as described previously for purine-derived CKs. However, its activity is higher, most probably because it cannot be enzymatically inactivated.

\section{Ability of CKs and CK Derivatives to Improve the Antioxidant Capacity and Secondary Metabolite Content}

CKs and their derivatives are often prepared for plant biotechnological applications and preferentially used in tissue cultures [3]. When particular CKs or their derivatives are employed in the micropropagation media of species with known antioxidant properties, plants exhibit increased antioxidant capacity through the explants grown [69]. In particular, a number of medicinal plants and often those high in antioxidants must be grown using micropropagation techniques due to their endangered status in nature. Such effects have been observed during the tissue culture and acclimatization of Merwilla plumbea, a plant widely used in traditional African medicine in Southern Africa and currently threatened in the wild because its medicinal use includes the bulbs [70]. Five CKs and their derivatives were evaluated during M. plumbea micropropagation: BAP, iP, $m \mathrm{~T}$, 3- $m \mathrm{TR}$ and 6-(3-methoxybenzyl)-9-(tetrahydropyran-2-ylamino)purine (meta-methoxytopolin THP, $m$ MTHP) [70]. The antioxidant activity and phenolic acid content during the tissue culture and acclimatization of the plantlets were determined. The findings indicated that the phytochemical content during in vitro propagation of M. plumbea were influenced by the CKs and the majority of the phenolic acids were higher in the tissue culture than in the acclimatized plantlets [70]. Similar effects on the secondary metabolite content were found in a study on micropropagated "Williams" banana. However, the activity of specific compounds differed for different plant species [69]. The influence of CKs from tissue culture media on flavonoid levels of micropropagated plantlets is important as flavonoids have been identified as compounds that are able to scavenge free radicals. [71]. TDZ was found to significantly influence shoot multiplication and accumulation of secondary metabolites in Scutellaria altissima culture. Scutellaria plants express several pharmacologically and clinically important phytochemicals [72]. In particular, the flavonoid verbascoside possesses strong anti-inflammatory, antibacterial, antiviral and antioxidant activity [73]. Under the conditions used in the study, 2.5 times more flavonoids and six-times more verbascoside were accumulated in shoots that were grown on the medium supplemented with CKs than in shoots that were grown on CK free medium [74]. In further work on Scutellaria altisima explants, a higher level of other important flavonoids, such as baicalin and wogonoside, were observed in 12-week-old micropropagated plants. The shoot cultures were grown on MS agar medium that was supplemented with BAP [75]. Wogonoside in particular is interesting as this flavonoid is very active against lipid peroxidation [76]. The medicinally important plant Eucomis autumnalis has been treated with $0.01,0.1$ and $10 \mu \mathrm{M}$ of 2-chloro-6-(3-methoxyphenylamino)purine (INCYDE) and CK antagonist 6-(2-hydroxy-3-methylbenzylamino)purine (PI-55) alone or in combination with $\mathrm{BAP}$ or naphthaleneacetic acid and the antioxidant response was evaluated in 10-week-old in vitro 
regenerates [77]. The levels of phytochemicals, especially those of flavonoids, were significantly affected by both tested compounds PI-55 as well as INCYDE. Besides, INCYDE application significantly increased the antioxidant activity of E. autumnalis in the DPPH test. On the other hand, the beta-carotene test was unaffected by INCYDE, however it was enhanced by BAP when it was used as a control [77]. Significantly improved antioxidant activity in the oxygen radical absorbance capacity (ORAC) assay was observed after one application of INCYDE in field-grown lettuce [78]. Both Kin and BAP enhanced the production of hypericins in Hypericium maculatum and hyperforin in H. hirsutum shoot cultures [79]. Naphthodianthrones (hypericin and pseudohypericin) and phloroglucinol hyperforin are valuable compounds that are associated with antiviral, antioxidant and other biological activities [80]. The increased flavonoid content and antioxidant activity of the common European herb sage (Salvia officinalis L.) has also been assessed during micropropagation [81]. The effects of four different CKs, i.e., TDZ, BAP, $\mathrm{Z}$ and iP, were evaluated. Levels of phytochemicals apigenin and its derivatives apigenin 7-methyl ether, scutellarein 6-methyl ether, scutellarein 6,7-dimethyl ether and luteolin were found to be comparable to those measured in plants grown on media without added CKs. On the other hand, BAP added to the media caused the production of hardened plants that successfully adapted in ex vitro conditions [81].

Aside from the above effects, $\mathrm{CKs}$ and their derivatives are able to influence the activity of antioxidant enzymes [35,82]. It was observed that the application of BAP prevents the degradation of chlorophyll in wheat senescent leaves and increases the activity of enzymes CAT and APX [35,83-85]. Increased SOD activity was observed after addition of $t Z R$ to the grass Agrostis palustris [86]. BAP also increased levels of the APX enzyme after four and six days' incubation of wheat leaves [35]. Application of BAP reduced $\mathrm{H}_{2} \mathrm{O}_{2}$ accumulation and lipid peroxidation of Litchi [83]. Furthermore, higher activity of SOD, CAT and APX and DPPH radical scavenging capacity were found in BAP treated Litchi. Data showing the influence of antioxidant compounds in different plant species are summarized in Table 1. It is apparent that the activity of individual CKs varies depending on the plant species and secondary metabolite group. However, whereas $\mathrm{H}_{2} \mathrm{O}_{2}$ and lipid peroxidation levels usually decrease after CK treatment, antioxidant enzymes CAT, APX and SOD, and antioxidant secondary metabolites, such as phenolic acids and flavonoids, increase.

Table 1. Effects of cytokinins on levels of antioxidant related enzymes, secondary metabolites and antioxidant activity in different assays. Arrows show $\uparrow$ increase or $\downarrow$ decrease in concentration or activity.

\begin{tabular}{|c|c|c|c|}
\hline Cytokinin & Plant & $\begin{array}{l}\text { Concentrations of Antioxidant Related Enzymes, } \\
\text { Secondary Metabolites and Antioxidant Activity }\end{array}$ & Reference \\
\hline \multirow{8}{*}{ BAP } & $\begin{array}{l}\text { St John's-wort (Hypericum } \\
\text { hirsutum sc.) }\end{array}$ & $\uparrow$ hyperforin & [79] \\
\hline & $\begin{array}{l}\text { St John's-wort (Hypericum } \\
\text { macalatum sc.) }\end{array}$ & $\uparrow$ pseudohypericin, hyperforin & [79] \\
\hline & Wheat (Triticum aestivum L.) leaves & $\uparrow \mathrm{CAT}, \uparrow \mathrm{APX}, \downarrow$ level of $\mathrm{H}_{2} \mathrm{O}_{2}$ & [35] \\
\hline & Litchi (Litchi chinensis Sonn). fruit & $\begin{array}{c}\uparrow \mathrm{SOD}, \uparrow \mathrm{CAT}, \uparrow \mathrm{APX}, \mathrm{DPPH} \text { assay } \\
\downarrow \text { level of } \mathrm{H}_{2} \mathrm{O}_{2}, \downarrow \text { lipid peroxidation, }\end{array}$ & [83] \\
\hline & $\begin{array}{c}\text { Skullcap (Scutellaria altisima) } \\
\text { explants }\end{array}$ & $\uparrow$ baicalin, $\uparrow$ wogonoside $\downarrow$ lipid peroxidation & [76] \\
\hline & $\begin{array}{l}\text { Eggplant (Solanum melongena L.) } \\
\text { plants }\end{array}$ & $\downarrow$ lipid peroxidation, $\uparrow \mathrm{SOD}, \uparrow \mathrm{CAT}, \uparrow \mathrm{POD}, \uparrow \mathrm{APX}$ & [84] \\
\hline & Wheat (JM20) plants & $\downarrow$ lipid peroxidation, $\uparrow \mathrm{SOD}, \uparrow \mathrm{CAT}, \uparrow \mathrm{POD}, \uparrow \mathrm{APX}$ & [85] \\
\hline & $\begin{array}{c}\text { Summer maize (hybrids } \\
\text { DengHai605, Zheng-Dan958) } \\
\text { plants }\end{array}$ & $\downarrow$ lipid peroxidation, $\uparrow$ SOD, $\uparrow$ CAT, $\uparrow \mathrm{POD}$ & [87] \\
\hline
\end{tabular}


Table 1. Cont.

\begin{tabular}{|c|c|c|c|}
\hline Cytokinin & Plant & $\begin{array}{l}\text { Concentrations of Antioxidant Related Enzymes, } \\
\text { Secondary Metabolites and Antioxidant Activity }\end{array}$ & Reference \\
\hline \multirow{2}{*}{ BAP } & $\begin{array}{l}\text { Rice (Oriza sativa cv. Taichung } \\
\text { Native 1) leaves }\end{array}$ & $\downarrow$ lipid peroxidation & [88] \\
\hline & \multirow{4}{*}{$\begin{array}{l}\text { Maerwilla (Merwilla plumbea) } \\
\text { explants }\end{array}$} & $\uparrow$ phenolic acids (PA, VA) & \multirow{4}{*}{ [70] } \\
\hline iP & & $\uparrow$ phenolic acid (CafA) & \\
\hline$m \mathrm{TR}$ & & $\uparrow$ phenolic acids (PA, FA, 4CA), ORAC & \\
\hline \multirow{2}{*}{$m \mathrm{~T}$} & & ORAC & \\
\hline & \multirow{2}{*}{$\begin{array}{l}\text { Banana (Musa spp. AAA cultivar } \\
\text { 'Williams') explants }\end{array}$} & $\uparrow$ total phenolics, $\uparrow$ proanthocyanidins & \multirow{2}{*}{ [69] } \\
\hline \multirow[b]{2}{*}{$m \mathrm{MTTHP}$} & & $\uparrow$ total phenolics, $\uparrow$ total flavonoids, $\uparrow$ proanthocynidins & \\
\hline & $\begin{array}{l}\text { Maerwilla (Merwilla plumbea) } \\
\text { explants }\end{array}$ & $\uparrow$ phenolic acids (4CA, FA) & [70] \\
\hline \multirow{2}{*}{$t Z R$} & $\begin{array}{l}\text { Creeping Bentgrass (Agrostis } \\
\text { palustris L.) plants }\end{array}$ & $\downarrow$ lipid peroxidation, $\downarrow$ electrolyte leakage, $\uparrow$ SOD, $\uparrow$ CAT & [86] \\
\hline & $\begin{array}{l}\text { Creeping Bentgrass (Agrostis } \\
\text { palustris L.) plants }\end{array}$ & $\downarrow$ lipid peroxidation, $\uparrow$ SOD, $\uparrow$ CAT & [89] \\
\hline TDZ & $\begin{array}{l}\text { Skullcap (Scutellaria alpina) } \\
\text { explants }\end{array}$ & $\uparrow$ flavonoids (BC, WO) $\uparrow$ verbascoside & [75] \\
\hline \multirow[b]{2}{*}{ CPPU } & Maize (Zea mays L.) seedlings & $\downarrow$ lipid peroxidation, $\downarrow$ level of $\mathrm{H}_{2} \mathrm{O}_{2}, \uparrow$ CAT & [90] \\
\hline & $\begin{array}{l}\text { Tomato (Lycopersicon esculentum } \\
\text { Mill.) leaves }\end{array}$ & $\downarrow$ lipid peroxidation, $\uparrow$ SOD, $\uparrow$ APX & [91] \\
\hline INCYDE & Lettuce (Lactuca sativa) & $\uparrow 4 \mathrm{CA}, \uparrow \mathrm{FA}, \mathrm{ORAC}$ & [78] \\
\hline PI-55 & Eucomis autumnalis explants & $\uparrow$ flavonoids, DPPH and $\beta$-carotene acid antioxidant assay & [77] \\
\hline \multirow{5}{*}{ Kin } & $\begin{array}{l}\text { St John's-wort (Hypericum } \\
\text { hirsutum sc.) }\end{array}$ & $\uparrow$ hyperforin & [79] \\
\hline & $\begin{array}{l}\text { St John's-wort (Hypericum } \\
\text { macalatum sc.) }\end{array}$ & $\uparrow$ pseudohypericin, hyperforin & [79] \\
\hline & $\begin{array}{c}\text { Tomato (Solanum lycopersicum L.) } \\
\text { plants }\end{array}$ & $\begin{array}{c}\downarrow \text { level of } \mathrm{H}_{2} \mathrm{O}_{2}, \downarrow \text { lipid peroxidation, } \downarrow \text { electrolyte leakage, } \\
\uparrow \mathrm{SOD}, \uparrow \mathrm{CAT}, \uparrow \text { ascorbate-glutathione cycle, } \uparrow \text { total phenols, } \\
\uparrow \text { flavonoids }\end{array}$ & [92] \\
\hline & $\begin{array}{c}\text { Oat (Avena sativa L. cv. Victory) } \\
\text { leaves }\end{array}$ & $\downarrow$ lipid peroxidation, $\uparrow$ SOD, $\uparrow$ CAT, & [29] \\
\hline & $\begin{array}{l}\text { Anthurium (Anthurium } \\
\text { andraeanum Lindl.) leaves }\end{array}$ & $\uparrow \mathrm{APX}$ & [82] \\
\hline
\end{tabular}

4CA, 4-coumaric acid; APX, ascorbate peroxidase; BAP, 6-(benzylamino)purine; BC, baicalin; CAT, catalase; CafA, caffeic acid; CPPU, $N$-(2-chloropyridin-4-yl)- $N^{\prime}$-phenylurea; DPPH, 2,2-diphenyl-1-picrylhydrazyl; FA, ferulic acid; INCYDE, 2-chloro-6-(3-methoxyphenylamino)purine; iP, 6-(2-isopentenylamino)purine; Kin, kinetin; mMTTHP, 6-(3-hydroxybenzylamino)purine-9-THP; mT, meta-topolin, 6-(3-hydroxybenzylamino)purine; mTR, 6-(3-hydroxybenzylamino)purine riboside; ORAC, oxygen radical absorbance capacity; PA, protocatechuic acid; PI-55, 6-(2-hydroxy-3-methylbenzylamino)purine; POD, peroxidase; sc, shoot culture; SOD, superoxide dismutase; TDZ, thidiazuron; tZR, trans-zeatin riboside; VA, vanillic acid; WO, wogonoside.

\section{CKs and (A)Biotic Stress Responses}

CKs play an important and complex role in abiotic stress responses [93]. Endogenous CK levels decrease when the plant is under abiotic stress, such as mineral, salt or drought stress. Transgenic plants overexpressing an IPT gene under the control of a maturation and drought-induced promoter were shown to recover from drought [94]. In addition, CKs were shown to enhance immunity to biotic stress [94]. Some pathogens are able to "use" host plants to produce high levels of CKs, such as the gram-negative bacterium Agrobacterium tumefaciens [95]. A. tumefaciens uses AHK3 and AHK4-dependent transcription reprogramming to make host cells more receptive to infection [96,97]. A similar situation occurs during infection by the gram-positive bacterium Rhodococcus fascians, which uses a higher CK production pool for leaf gall formation and extending the ectopic growing shoot primordia [97-99]. Some fungal pathogens also produce CKs, such as the ergot fungus Claviceps purpurea, which infects the ovaries of rye [100]. These pathogens reprogramme the 
biosynthesis of CKs for more extensive infection. On the other hand, exogenous application of CKs affects salicylic acid mediated defence responses, e.g., in Pseudomonas syringae pv. tomato $[97,101]$.

CKs have been suggested to be instrumental in mediating host susceptibility to fungal biotrophs by generating a green island around infection zones $[102,103]$. Although CKs are undoubtedly involved in defence mechanisms against biotic stress, their production often accompanies attack by particular phytopathogens. There is evidence that the reduction in photosynthesis in infected leaves results from increased invertase activity [103]. Paradoxically, infection seems to have a positive effect on antisenescent processes in the host plant as part of the protection of chlorophyll against disintegration (green islands). This antisenescent "improvement" is probably induced by the pathogen to gain more plant material for spreading its infection. However, although we know some of the ways by which these pathogens affect antisenescent responses, much remains unknown.

\section{CKs and Photosynthesis}

The main function of leaves is to provide assimilates for plant growth through photosynthesis. CKs affect the functional as well as the structural aspects of photosynthesis at several levels. CKs induce cell division and differentiation even in the early stages of leaf development. Chernyaev et al. studied and reviewed the effect of CKs at the level of the whole leaf and found that they changed the leaf structure to have a greater number of cells per leaf area [104] and a larger number of vascular bundles and xylem and phloem elements [105]. Another structure closely connected to photosynthesis at the leaf level is the stomata. CKs acting as antagonists of abscisic acid can increase stomatal conductance $[61,92,106-108]$ and, thus, modulate leaf gas exchange and the availability of $\mathrm{CO}_{2}$ - the essential substrate for photosynthetically active tissue [6].

At the cellular level, CKs have a major effect on chloroplasts. As early as 1969, Boasson and Laetsch [109] reported that when etiolated tobacco leaves were transferred to light, the application of CKs increased the number of chloroplasts. Further research confirmed that CKs promoted the differentiation of etioplasts, their transition to chloroplasts [110-112], chloroplast division [113] and, finally, increased the number of chloroplasts [114]. In the presence of BAP, greening and plastid biogenesis in Lupines lutus and Cucumis sativus were substantially promoted [115,116]. Concurrently, a higher concentration and slower degradation of light-sensitive protochlorophyllide oxidoreductase, a key enzyme in chlorophyll biosynthesis, was observed in Lupines lutus and Cucumis sativus cotyledons $[115,116]$.

At the level of the thylakoid membrane, it has been observed that CKs promote grana formation $[110,117,118]$ and increase the content of photosynthetically active pigments [118-120] and starch grains [117,121-124]. CK regulation of chloroplast development, chlorophyll biosynthesis and nuclear plastid-related as well as plastid genes have been reviewed recently (for further reading, see [125]). CKs are reported to affect pigment-protein complexes involved in the light (primary) phase of photosynthesis, as well as enzymes of the dark (secondary) phase. Of the genes most upregulated by $\mathrm{CKs}$, the most widely documented genes are those coding for the light-harvesting chlorophyll $a / b$ binding proteins of photosystem II (CAB) and small and large subunits of RUBISCO (RBCS, $R B C L)[112,126,127]$.

A close relationship between CKs and chloroplasts was confirmed by work showing that chloroplasts contain CKs of endogenous origin [128-130]. Chloroplasts of Arabidopsis contain four of seven IPT enzymes (AtIPT1, AtIPT3, AtIPT5 and AtIPT8) that catalyse the rate-limiting step of CK biosynthesis [129]. Senescence as the final stage in leaf development is accompanied by a decrease in CK content. Ananieva et al. [131,132] showed that progression of senescence of zucchini cotyledons correlated with a gradual decrease in the concentration of physiologically active CKs, together with an increase in the storage CK O-glucosides. Similarly, the content of active CK forms decreased in detached wheat and Arabidopsis leaves senescing in darkness [133,134].

As the photosynthetic apparatus is a possible source of ROS that may lead to destruction of assimilates that are intended for transport to growing or store tissue, its decomposition 
during senescence is highly regulated. In this regulation, CKs again play an important part. During senescence, changes in the chloroplast ultrastructure are well-documented, such as alterations in size and shape, disorganization of the thylakoid membrane, increased number of plastoglobuli and decreased chlorophyll content and photosynthesis function (for a review, see [135]). Application of exogenous CKs usually slows down typical senescence-induced changes, e.g., chlorophyll content decrease $[119,123,136-138]$, plastoglobuli formation $[118,121,139]$ and drop in key photosynthetic parameters, such as the rate of $\mathrm{CO}_{2}$ assimilation $(A)[6,87,92,140,141]$, photochemical quenching (qP) and maximal photochemical efficiency of PSII $\left(F_{\mathrm{v}} / F_{\mathrm{m}}\right)[87,91,92,123,142,143]$. The senescence decelerating effect of CKs is not only connected to the upregulation of genes for biosynthesis and protection, however also to the downregulation of SAGs $[144,145]$ and CK-mediated inhibition of degrading enzymes (e.g., activity of chlorophyllase, Mg-dechelatase, chlorophyll degrading peroxidase [146], RNase activity [147] and expression of pheophytinase [148]).

The effect of each CK ligand depends not only on its structure and concentration, however it also may be species-specific. Various CKs show modified ligand affinity for their receptors, e.g., in A. thaliana, Brasica napus, maize and potato [22,149-151]. The diverse effects of particular CKs regarding physiological responses to exogenous application have also been documented. Whereas BAP is widely known for its antisenescence effect on leaves of, e.g., broccoli, bean, barley, maize and wheat $[85,87,137,152,153]$, after application to lettuce, no or only a weak effect was found $[152,154]$. Similarly, kin has repeatedly been reported as very active in senescence deceleration (e.g., [155-157]), however it showed an ambiguous effect on Anthurium [82]. It should be noted that the CK effect also depends on the age of cells and leaves [158] and light conditions [123,158,159].

\section{Mechanisms and Genes Implicated in the Antisenescent and Antioxidant Activity of CKs}

The ability of plants to perceive CKs acts through a modified bacterial two-component pathway that functions via a multi-step phosphorelay [160]. CK molecules in Arabidopsis are perceived by sensor histidine kinase receptors, named AHK2, AHK3 and CRE1/AHK4 [161-163]. Gene responses to CK treatment have been examined and reported a number of times $[93,161,164]$. The first genes to be induced by CKs (IBC genes), now known as A response regulator genes ARR5 and ARR4, were identified in 1998 [161,165]. AHK3 in particular was found to be the major Arabidopsis CK receptor connected with the antisenescent effect of CKs. It also plays a major role in CK-mediated leaf longevity through specific phosphorylation of a type-B response regulator, ARR2 [23,166]. Zwack et al. [167] showed that cytokinin response factor 6 (CRF6), the expression of which is downstream of the perception of CKs by AHK3, is involved in negative regulation of senescence. Recent research demonstrated that AHK2 and AHK3 are implicated in the routine repair of D1 protein, which is necessary for the functioning of photosystem II (PSII). This protective function of CKs during light stress depends on type B ARR1 and ARR12 [168]. On the other hand, the receptor CRE1/AHK4 probably affects oxidative damage during senescence. Janečková et al. [134] studied Arabidopsis mutants with two non-functional and only one functional CK AHK receptor and observed that the dark senescence induced increase in lipid peroxidation was retarded in the mutant with solely functional CRE1/AHK4 and also partially in the mutant with solely functional AHK2 receptor. Different patterns of hormonal regulation suggest that CKs may act transcriptionally to alter responses to ROS that are often produced during abiotic stress [93]. Over the last 10 years, using the model Arabidopsis plant, several transcriptomic datasets related to CKs have been generated from different technological platforms, culminating in RNA sequencing [164]. It is well-known today that both exogenous application of active CKs and an increase in their endogenous content can delay senescence $[6,134,169]$. Current molecular genetics strategies to manipulate leaf senescence are based either on enhancing CK production $[6,7]$ and perception [170] or exogenous application of CKs and their derivatives [6,171]. It was shown that it is possible to genetically engineer IPT plants to overproduce CKs [6,7]. These IPT plants as well as exogenously added CKs, e.g., BAP, can be used in vegetables such as broccoli to effectively delay senescence as well as postharvest senescence owing to their antagonistic effect on ethylene [172]. 
Functional analysis of differentially expressed genes in BAP supplied postharvest broccoli showed regulation in the expression of genes involved in CK signalling, nutrient transport and photosynthesis. The addition of BAP caused downregulation of the gene responsible for ethylene synthesis [172]. Flowers of Petunia $x$ hybrida transformed with PSAG12-IPT that overproduced endogenous CKs during the senescence period and produced the same amount of ethylene as wild-type flowers, however were less sensitive to exogenous ethylene and had a much longer lifetime [173]. This demonstrates that endogenous CKs lower the sensitivity of plants to ethylene and extend their lifetime.

Many genes associated with senescence (SAGs) have been identified [174]. SAGs are genes that are expressed during senescence [170] that encode for degradative enzymes, such as RNAses [175], proteinases [176-178] and lipases [179], and products involved in nutrient translocation processes [180]. Temporal control of senescence was achieved when the promoter of the SAG12 gene was linked to an IPT gene [94]. The SAG12::IPT autoregulatory senescence inhibition system has also been successfully implemented in a number of important crops, such as rice, ryegrass, tomato, alfalfa, cauliflower, wheat, cassava and cotton [171,181]. Currently, it is used to delay senescence in green vegetables, such as lettuce and broccoli [94]. PSAG12-IPT tobacco plants that were grown in a growth-limiting nitrogen supply showed delayed senescence-associated declines in nitrogen, protein and Rubisco levels and photosynthesis rates [182]. Weaver and Gan published the expression of several Arabidopsis thaliana SAGs in attached and/or detached leaves and compared the response to age, dehydration, darkness, abscisic acid, cytokinin (BAP) and ethylene treatment [144]. BAP inhibited SAG expression in dark detachment experiments and the inhibition was generally greater in younger leaves. Thus, there is an indisputable connection between CK action and the light influence on senescence as the key factors in senescence regulation [134]. Lara et al. demonstrated that CKs upregulate the expression of extracellular cell wall invertase and that this enzyme is required for the delay of senescence caused by CKs [183]. This enzyme plays a crucial role in source-sink regulation, which has been shown to be a key molecular mechanism in CK senescence inhibition [183]. Vylíčilová et al. prepared a series of 2,6-disubstituted ARCK derivatives in 2016 and investigated the relation between the antisenescent effect of these compounds derived from CKs and their influence on photosystem II [44]. For most of the active compounds, regulation of gene expression in senescent Arabidopsis leaves was observed. In agreement with previously published data, it was shown that CK derivative treatment upregulated CK response regulators and other CK responsive genes, such as ARR15, ARR5, ARR8, ARR7, ARR4, ARR6, ARR9, CKX4, CRE1/AHK4, CRF2 and CRF5, however also genes encoding components of the photosystem II light harvesting complex (LHCII), i.e., At2g05070, At5g54270, At1g44575, At3g55330 and At2g39470, even though BAP had a negligible effect on these genes [44]. This supports the abovementioned suggestion of the need for electronegative atoms (which BAP lacks) in the vicinity of $\mathrm{N} 6 \mathrm{H}$ and N7H.

Transgenic plants have also been used to examine the influence of endogenous CKs on antioxidant defence systems. CKs induced the activity of antioxidant enzymes in transgenic plants, e.g., during plant ontogeny of Pssu-ipt tobacco [184]. Whereas the control plants showed a decline in total CK content, the transgenic plants exhibited at least a 10 times higher content of CKs than the controls, especially of $Z$ and $Z R$. The transgenic plants also showed elevated activity of antioxidant enzymes,

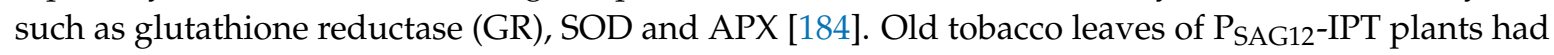
a much longer lifespan and the concentrations of antioxidants ascorbate and GSH were higher than in wild-type leaves. At the same time, the chlorophyll and protein contents together with photosynthetic rate were increased. The decline in activity of antioxidative enzymes APX, GR and SOD during

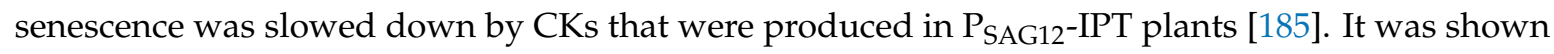
that old leaves of $\mathrm{P}_{\mathrm{SAG12}}$-IPT plants and their chloroplasts maintained higher physiological parameters than in the control due to the extension of the period of greater antioxidant protection [186]. In a field study, stay-green cv. P3845 of Zea mays with enhanced levels of endogenous CKs showed higher CAT and SOD activities than earlier senescent cv. Hokku 55 [187]. 
The effects of exogenous CKs on photosynthetic capacity and antioxidant enzyme activities were evaluated in WN6 (a stay-green wheat cultivar) and JM 20 (control wheat, [85]). WN6 reached a higher grain mass, mainly due to a higher photosynthetic rate resulting from a maximal quantum yield of PSII photochemistry. Exogenously applied BAP enhanced antioxidant enzyme activities and decreased MDA content, as well as increased endogenous $t Z$ levels [85].

\section{Conclusions}

Here, we review a family of important plant growth regulators-CKs-that are inseparably linked with plant senescence. The emphasis is on the interconnections between the CK influence on the photosynthetic apparatus, determinable antisenescent properties measured by several bioassays, antioxidative enzyme regulation, levels of antioxidant secondary metabolites in a number of plants or their explants and genes involved in plant senescence and its regulation. We highlight several molecular aspects that may represent new connections in the mechanism of action of these amazing small molecules that are indisputably involved in plant defence against biotic and abiotic stress. The role of systematic study and synthesis of new CK derivatives in relation to their biological functions is discussed, especially their antisenescent properties, together with their structural changes in comparison to the original molecules. Links between changes in structure and biological activities, especially effects on photosynthetic apparatus, secondary metabolite production and senescence related gene involvement, are described with regard to the overall functions of CKs within plants. Common structural motifs in CK molecules that could serve as a guide to specifically why these molecules have antisenescent properties are outlined. The involvement and ability of biotic stresses to enter the transcriptional process of CK production are also mentioned. This is especially relevant to green island formation and the influence on photosynthesis, which continue to be important issues. However, many questions remain which need further exploration of these interesting molecules with ancient perception and regulatory systems.

Funding: The work was supported by an ERDF project entitled "Development of Pre-Applied Research in Nanotechnology and Biotechnology" (No. CZ.02.1.01/0.0/0.0/17_048/0007323), grant No. LO1204 (Sustainable Development of Research in the Centre of the Region Haná) from the National Program of Sustainability I, Ministry of Education, Youth and Sports, Czech Republic; as well as by the Internal Grant Agency of Palacký University (IGA_PrF_2018_023).

Acknowledgments: We would like to thank Sees-editing Ltd for Englishpaper editing.

Conflicts of Interest: The authors declare no conflicts of interest.

\section{Abbreviations}

2Cl-3F-BAPR 2-chloro-6-(3-fluorobenzylamino)-9- $\beta$-D-ribofuranosylpurine

3F-BAP 6-(3-fluorobenzylamino)purine

3F-BAPR 6-(3-fluorobenzylamino)-9- $\beta$-D-ribofuranosylpurine

AHK Arabidopsis histidine kinase

APX ascorbate peroxidase

ARCK aromatic cytokinins

ARR Arabidopsis response regulator

BAP 6-(benzylamino)purine

CAT catalase

CK cytokinin

CPPU $\quad N$-(2-chloropyridin-4-yl)-N'-phenylurea

CRF cytokinin response factor

$c Z \quad$ 6-(Z)-(4-hydroxy-3-methylbut-2-enylamino)purine (cis-zeatin)

DCPPU $\quad N-\left(2,6-\right.$ dichloro-pyridin-4-yl)- $N^{\prime}$-phenylurea

DHZ 6-(4-hydroxy-3-methylbutylamino)purine (dihydrozeatin)

DHZR 6-(4-hydroxy-3-methylbutylamino)-9- $\beta$-D-ribofuranosylpurine (dihydrozeatin-riboside)

GSH glutathione 


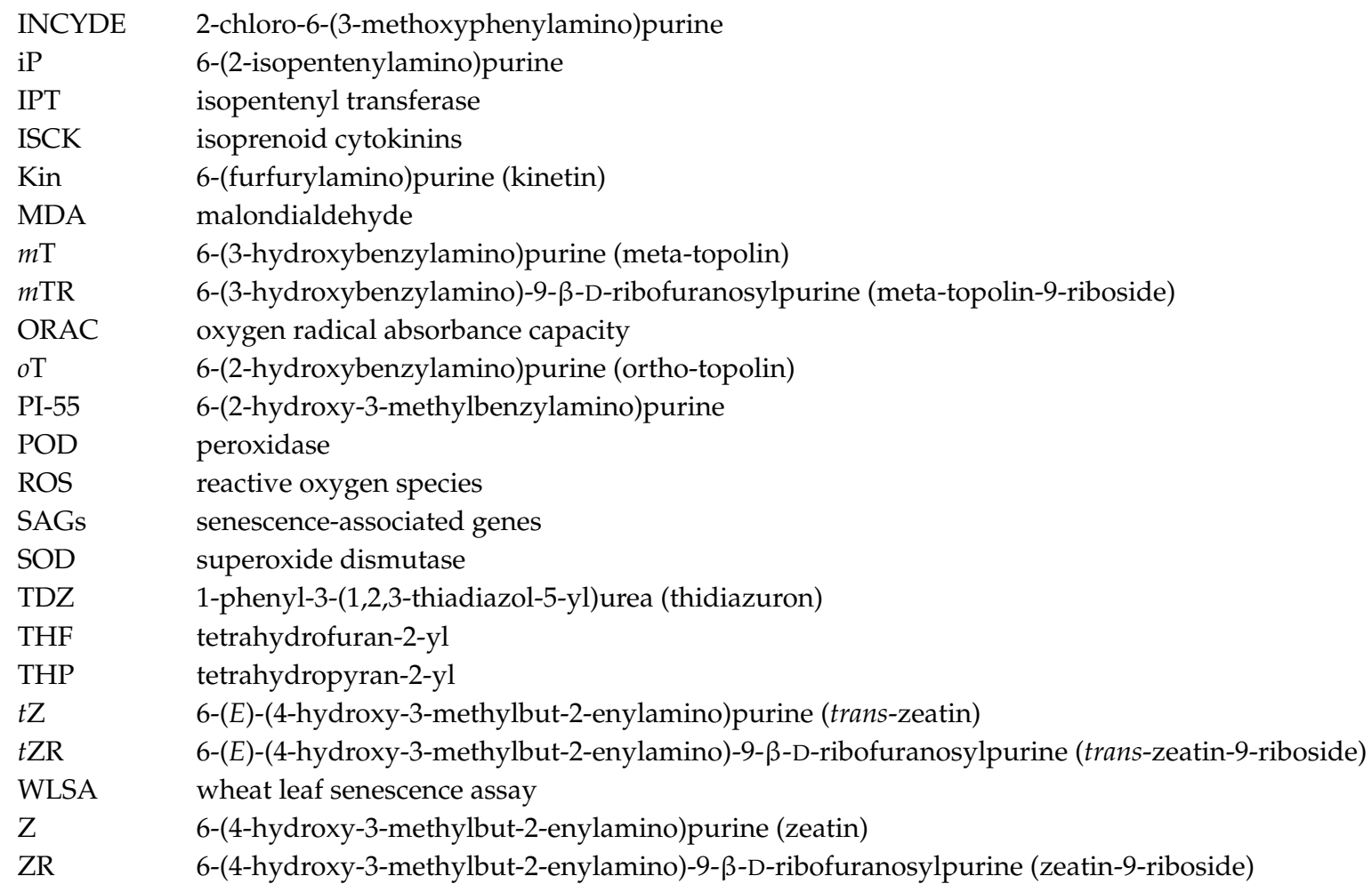

\section{References}

1. Davies, P.J. Plant Hormones; Davies, P.J., Ed.; Springer: Dordrecht, The Netherlands, 2010; ISBN 978-1-4020-2684-3.

2. Strnad, M. The aromatic cytokinins. Physiol. Plant. 1997, 101, 674-688. [CrossRef]

3. Plíhalová, L.; Vylíčilová, H.; Doležal, K.; Zahajská, L.; Zatloukal, M.; Strnad, M. Synthesis of aromatic cytokinins for plant biotechnology. New Biotechnol. 2016, 33, 614-624. [CrossRef] [PubMed]

4. Mok, D.W.S.; Mok, M.C. Cytokinin metabolism and action. Annu. Rev. Plant Physiol. Plant Mol. Biol. 2001, 52, 89-118. [CrossRef] [PubMed]

5. Van Staden, J. Cytokinins and senescence. Senescence Aging Plants 1988, 281-328. [CrossRef]

6. Gan, S.; Amasino, R.M. Inhibition of leaf senescence by autoregulated production of cytokinin. Science 1995, 270, 1986-1988. [CrossRef] [PubMed]

7. Rivero, R.M.; Kojima, M.; Gepstein, A.; Sakakibara, H.; Mittler, R.; Gepstein, S.; Blumwald, E. Delayed leaf senescence induces extreme drought tolerance in a flowering plant. Proc. Natl. Acad. Sci. USA 2007, 104, 19631-19636. [CrossRef] [PubMed]

8. Koprna, R.; de Diego, N.; Dundálková, L.; Spíchal, L. Use of cytokinins as agrochemicals. Bioorg. Med. Chem. 2016, 24, 484-492. [CrossRef] [PubMed]

9. Koyama, T. A hidden link between leaf development and senescence. Plant Sci. 2018, 276, 105-110. [CrossRef]

10. Toscano, S.; Trivellini, A.; Ferrante, A.; Romano, D. Physiological mechanisms for delaying the leaf yellowing of potted geranium plants. Sci. Hortic. 2018, 242, 146-154. [CrossRef]

11. Kulaeva, O.N. The influence of roots on leaf metabolism in relation to kinetin action. Sov. Plant Physiol. 1962, 9, 229-239.

12. Brizzolari, A.; Marinello, C.; Carini, M.; Santaniello, E.; Biondi, P.A. Evaluation of the antioxidant activity and capacity of some natural N6-substituted adenine derivatives (cytokinins) by fluorimetric and spectrophotometric assays. J. Chromatogr. B Anal. Technol. Biomed. Life Sci. 2016, 1019, 164-168. [CrossRef]

13. Vanacker, H. Roles for redox regulation in leaf senescence of pea plants grown on different sources of nitrogen nutrition. J. Exp. Bot. 2006, 57, 1735-1745. [CrossRef] [PubMed]

14. Pilarska, M.; Skowron, E.; Pietraś, R.; Krupinska, K.; Niewiadomska, E. Changes in lipid peroxidation in stay-green leaves of tobacco with senescence-induced synthesis of cytokinins. Plant Physiol. Biochem. 2017, 118, 161-167. [CrossRef] [PubMed] 
15. Zimmermann, P.; Heinlein, C.; Orendi, G.; Zentgraf, U. Senescence-specific regulation of catalases in Arabidopsis thaliana (L.) Heynh. Plant, Cell Environ. 2006, 29, 1049-1060. [CrossRef]

16. Richmond, A.E.; Lang, A. Effect of kinetin on protein content and survival of detached Xanthium leaves. Science 1957, 125, 650-651. [CrossRef]

17. Dyer, T.A.; Osborne, D.J. Leaf nucleic acids. J. Exp. Bot. 1971, 22, 552-560. [CrossRef]

18. Kamínek, M.; Luštinec, J. Sensitivity of oat leaf chlorophyll retention bioassay to natural and synthetic cytokinins. Biol. Plant. 1978, 20,377-382. [CrossRef]

19. Holub, J.; Hanuš, J.; Hanke, D.E.; Strnad, M. Biological activity of cytokinins derived from Ortho- and Meta-hydroxybenzyladenine. Plant Growth Regul. 1998, 26, 109-115. [CrossRef]

20. Gajdošová, S.; Spíchal, L.; Kamínek, M.; Hoyerová, K.; Novák, O.; Dobrev, P.I.; Galuszka, P.; Klíma, P.; Gaudinová, A.; Žižková, E.; et al. Distribution, biological activities, metabolism, and the conceivable function of cis-zeatin-type cytokinins in plants. J. Exp. Bot. 2011, 62, 2827-2840. [CrossRef] [PubMed]

21. Mik, V.; Szüčová, L.; Spíchal, L.; Plíhal, O.; Nisler, J.; Zahajská, L.; Doležal, K.; Strnad, M. N9-Substituted N6-[(3-methylbut-2-en-1-yl)amino]purine derivatives and their biological activity in selected cytokinin bioassays. Bioorg. Med. Chem. 2011, 19, 7244-7251. [CrossRef] [PubMed]

22. Spíchal, L.; Rakova, N.Y.; Riefler, M.; Mizuno, T.; Romanov, G.A.; Strnad, M.; Schmülling, T. Two cytokinin receptors of Arabidopsis thaliana, CRE1/AHK4 and AHK3, differ in their ligand specificity in a bacterial assay. Plant Cell Physiol. 2004, 45, 1299-1305. [CrossRef] [PubMed]

23. Kim, H.J.; Ryu, H.; Hong, S.H.; Woo, H.R.; Lim, P.O.; Lee, I.C.; Sheen, J.; Nam, H.G.; Hwang, I. Cytokinin-mediated control of leaf longevity by AHK3 through phosphorylation of ARR2 in Arabidopsis. Proc. Natl. Acad. Sci. USA 2006, 103, 814-819. [CrossRef] [PubMed]

24. Doležal, K.; Popa, I.; Kryštof, V.; Spíchal, L.; Fojtíková, M.; Holub, J.; Lenobel, R.; Schmülling, T.; Strnad, M. Preparation and biological activity of 6-benzylaminopurine derivatives in plants and human cancer cells. Bioorganic Med. Chem. 2006, 14, 875-884. [CrossRef]

25. Gan, S.; Amasino, R. Cytokinins in plant senescence: From spray and pray to clone and play. BioEssays 1996, 18, 557-565. [CrossRef]

26. Noodén, L.D.; Singh, S.; Letham, D.S. Correlation of xylem sap cytokinin levels with monocarpic senescence in soybean. Plant Physiol. 1990, 93, 33-39. [CrossRef] [PubMed]

27. Singh, S.; Letham, D.S.; Palni, L.M.S. Cytokinin biochemistry in relation to leaf senescence. VII. Endogenous cytokinin levels and exogenous applications of cytokinins in relation to sequential leaf senescence of tobacco. Physiol. Plant. 1992, 86, 388-397. [CrossRef]

28. Podlešáková, K.; Zalabák, D.; Čudejková, M.; Plíhal, O.; Szüčová, L.; Doležal, K.; Spíchal, L.; Strnad, M.; Galuszka, P. Novel cytokinin derivatives do not show negative effects on root growth and proliferation in submicromolar range. PLoS ONE 2012, 7, e39293. [CrossRef]

29. Dhindsa, R.S.; Plumb-Dhindsa, P.L.; Reid, D.M. Leaf senescence and lipid peroxidation: Effects of some phytohormones, and scavengers of free radicals and singlet oxygen. Physiol. Plant. 1982, 56, 453-457. [CrossRef]

30. Del Río, L.A.; Pastori, G.M.; Palma, J.M.; Sandalio, L.M.; Sevilla, F.; Corpas, F.J.; Jiménez, A.; López-Huertas, E.; Hernández, J.A. The activated oxygen role of peroxisomes in senescence. Plant Physiol. 1998, 116, 1195-1200. [CrossRef]

31. Jiao, D.; Ji, B.; Li, X. Characteristics of chlorophyll fluorescence and membrane-lipid peroxidation during senescence of flag leaf in different cultivars of rice. Photosynthetica 2003, 41, 33-41. [CrossRef]

32. Cabello, P.; Agüera, E.; de la Haba, P. Metabolic changes during natural ageing in sunflower (Helianthus annuus) leaves: Expression and activity of glutamine synthetase isoforms are regulated differently during senescence. Physiol. Plant. 2006, 128, 175-185. [CrossRef]

33. Jajić, I.; Sarna, T.; Szewczyk, G.; Strzałka, K. Changes in production of reactive oxygen species in illuminated thylakoids isolated during development and senescence of barley. J. Plant Physiol. 2015, 184, 49-56. [CrossRef] [PubMed]

34. Mik, V.; Szüčová, L.; Šmehilová, M.; Zatloukal, M.; Doležal, K.; Nisler, J.; Grúz, J.; Galuszka, P.; Strnad, M.; Spíchal, L. N9-substituted derivatives of kinetin: Effective anti-senescence agents. Phytochemistry 2011, 72, 821-831. [CrossRef] [PubMed] 
35. Zavaleta-Mancera, H.A.; López-Delgado, H.; Loza-Tavera, H.; Mora-Herrera, M.; Trevilla-García, C.; Vargas-Suárez, M.; Ougham, H. Cytokinin promotes catalase and ascorbate peroxidase activities and preserves the chloroplast integrity during dark-senescence. J. Plant Physiol. 2007, 164, 1572-1582. [CrossRef] [PubMed]

36. Novák, J.; Pavlů, J.; Novák, O.; Nožková-Hlaváčková, V.; Špundová, M.; Hlavinka, J.; Koukalová, Š.; Skalák, J.; Černý, M.; Brzobohatý, B. High cytokinin levels induce a hypersensitive-like response in tobacco. Ann. Bot. 2013, 112, 41-55. [CrossRef] [PubMed]

37. Zhang, R.; David, L.S. Cytokinin biochemistry in relation to leaf senescence. III. The senescence-retarding activity and metabolism of 9-substituted 6-benzylaminopurines in soybean leaves. J. Plant Growth Regul. 1989, 8, 181-197. [CrossRef]

38. Corse, J.; Pacovsky, R.S.; Lyman, M.L.; Brandon, D.L. Biological activity of several 9-nonglycosidic-substituted natural cytokinins. J. Plant Growth Regul. 1989, 8, 211-223. [CrossRef]

39. Szüčová, L.; Spíchal, L.; Doležal, K.; Zatloukal, M.; Greplová, J.; Galuszka, P.; Kryštof, V.; Voller, J.; Popa, I.; Massino, F.J.; et al. Synthesis, characterization and biological activity of ring-substituted 6-benzylamino-9-tetrahydropyran-2-yl and 9-tetrahydrofuran-2-ylpurine derivatives. Bioorganic Med. Chem. 2009, 17, 1938-1947. [CrossRef]

40. Szüčová, L.; Zatloukal, M.; Spíchal, L.; Fröhlich, L.; Doležal, K.; Strnad, M.; Massino, F. 6,9-Disubstituted Purine Derivatives and their Use for Treating Skin. Patent EP 2043630, 10 May 2016.

41. Szüčová, L.; Zatloukal, M.; Spíchal, L.; Voller, J.; Doležal, K.; Strnad, M.; Massino, F.J. 6,9-Disubstituted Purine Derivatives and Their Use as Cosmetics and Cosmetic Compositions. Patent US7960397, 14 June 2011.

42. Zatloukal, M.; Gemrotová, M.; Doležal, K.; Havlíček, L.; Spíchal, L.; Strnad, M. Novel potent inhibitors of $A$. thaliana cytokinin oxidase/dehydrogenase. Bioorg. Med. Chem. 2008, 16, 9268-9275. [CrossRef]

43. Doležal, K.; Popa, I.; Hauserová, E.; Spíchal, L.; Chakrabarty, K.; Novák, O.; Kryštof, V.; Voller, J.; Holub, J.; Strnad, M. Preparation, biological activity and endogenous occurrence of N6-benzyladenosines. Bioorg. Med. Chem. 2007, 15, 3737-3747. [CrossRef]

44. Vylíčilová, H.; Husičková, A.; Spíchal, L.; Srovnal, J.; Doležal, K.; Plíhal, O.; Plíhalová, L. C2-substituted aromatic cytokinin sugar conjugates delay the onset of senescence by maintaining the activity of the photosynthetic apparatus. Phytochemistry 2016, 122, 22-33. [CrossRef] [PubMed]

45. Hönig, M.; Plíhalová, L.; Spíchal, L.; Grúz, J.; Kadlecová, A.; Voller, J.; Svobodová, A.R.; Vostálová, J.; Ulrichová, J.; Doležal, K.; Strnad, M. New cytokinin derivatives possess UVA and UVB photoprotective effect on human skin cells and prevent oxidative stress. Eur. J. Med. Chem. 2018, 150, 946-957. [CrossRef] [PubMed]

46. Bråthe, A.; Andresen, G.; Gundersen, L.L.; Malterud, K.E.; Rise, F. Antioxidant activity of synthetic cytokinin analogues: 6-Alkynyl- and 6-alkenylpurines as novel 15-lipoxygenase inhibitors. Bioorg. Med. Chem. 2002, 10, 1581-1586. [CrossRef]

47. Zahajská, L.; Nisler, J.; Voller, J.; Gucký, T.; Pospíšil, T.; Spíchal, L.; Strnad, M. Preparation, characterization and biological activity of C8-substituted cytokinins. Phytochemistry 2017, 135, 115-127. [CrossRef] [PubMed]

48. Skoog, F.; Hamzi, H.Q.; Szweykowska, A.M.; Leonard, N.J.; Carraway, K.L.; Fujii, T.; Helgeson, J.P.; Loeppky, R.N. Cytokinins: Structure/activity relationships. Phytochemistry 1967, 6, 1169-1192. [CrossRef]

49. Nisler, J.; Zatloukal, M.; Sobotka, R.; Pilný, J.; Zdvihalová, B.; Novák, O.; Strnad, M.; Spíchal, L. New urea derivatives are effective anti-senescence compounds acting most likely via a cytokinin-independent mechanism. Front. Plant Sci. 2018, 9, 1-17. [CrossRef] [PubMed]

50. Mok, M.C.; Mok, D.W.S.; Armstrong, D.J.; Shudo, K.; Isogai, Y.; Okamoto, T. Cytokinin activity of $N$-phenyl- $N^{\prime}$-1,2,3-thiadiazol-5-ylurea (thidiazuron). Phytochemistry 1982, 21, 1509-1511. [CrossRef]

51. Thomas, J.C.; Katterman, F.R. Cytokinin activity induced by thidiazuron. Plant Physiol. 1986, 81, 681-683. [CrossRef]

52. Ferrante, A.; Hunter, D.A.; Hackett, W.P.; Reid, M.S. Thidiazuron-A potent inhibitor of leaf senescence in Alstroemeria. Postharvest Biol. Technol. 2002, 25, 333-338. [CrossRef]

53. Ferrante, A.; Tognoni, F.; Mensuali-Sodi, A.; Serra, G. Treatment with thidiazuron for preventing leaf yellowing in cut tulips and Chrysanthemum. Acta Hortic. 2003, 357-363. [CrossRef]

54. Mutui, T.; Mibus, H.; Serek, M. Effects of thidiazuron, ethylene, abscisic acid and dark storage on leaf yellowing and rooting of Pelargonium cuttings. J. Hortic. Sci. Biotechnol. 2005, 80, 543-550. [CrossRef] 
55. Nisler, J. TDZ: Mode of Action, Use and Potential in Agriculture. In Thidiazuron: From Urea Derivative to Plant Growth Regulator; Ahmad, N., Faisal, M., Eds.; Springer: Singapore, 2018; pp. 37-59.

56. Whitty, C.D.; Hall, R.H. A Cytokinin Oxidase in Zea mays. Can. J. Biochem. 1974, 52, 789-799. [CrossRef] [PubMed]

57. Brownlee, B.G.; Hall, R.H.; Whitty, C.D. 3-Methyl-2-butenal: An Enzymatic Degradation Product of the Cytokinin, N6-( $\Delta 2-$ Isopentenyl)adenine. Can. J. Biochem. 1975, 53, 37-41. [CrossRef] [PubMed]

58. Chatfield, J.M.; Armstrong, D.J. Regulation of cytokinin oxidase activity in callus tissues of Phaseolus vulgaris L. cv great northern. Plant Physiol. 1986, 80, 493-499. [CrossRef] [PubMed]

59. Kopečný, D.; Briozzo, P.; Popelková, H.; Šebela, M.; Končitíková, R.; Spíchal, L.; Nisler, J.; Madzak, C.; Frébort, I.; Laloue, M.; Houba-Hérin, N. Phenyl- and benzylurea cytokinins as competitive inhibitors of cytokinin oxidase/dehydrogenase: A structural study. Biochimie 2010, 92, 1052-1062. [CrossRef] [PubMed]

60. Nisler, J.; Kopečný, D.; Končitíková, R.; Zatloukal, M.; Bazgier, V.; Berka, K.; Zalabák, D.; Briozzo, P.; Strnad, M.; Spíchal, L. Novel thidiazuron-derived inhibitors of cytokinin oxidase/dehydrogenase. Plant Mol. Biol. 2016, 92, 235-248. [CrossRef] [PubMed]

61. Ferrante, A.; Vernieri, P.; Serra, G.; Tognoni, F. Changes in abscisic acid during leaf yellowing of cut stock flowers. Plant Growth Regul. 2004, 43, 127-134. [CrossRef]

62. Mayak, S.; Halevy, A.H. Interrelationships of Ethylene and abscisic acid in the control of rose petal senescence. Plant Physiol. 1972, 50, 341-346. [CrossRef]

63. Cutler, S.R.; Rodriguez, P.L.; Finkelstein, R.R.; Abrams, S.R. Abscisic acid: Emergence of a core signaling network. Annu. Rev. Plant Biol. 2010, 61, 651-679. [CrossRef]

64. Mutui, T.M.; Mibus, H.; Serek, M. Influence of thidiazuron, ethylene, abscisic acid and dark storage on the expression levels of ethylene receptors (ETR) and ACC synthase (ACS) genes in Pelargonium. Plant Growth Regul. 2007, 53, 87-96. [CrossRef]

65. Abeles, F.B.; Dunn, L.J.; Morgens, P.; Callahan, A.; Dinterman, R.E.; Schmidt, J. Induction of 33-kD and 60-kD peroxidases during ethylene-induced senescence of cucumber cotyledons. Plant Physiol. 1988, 87, 609-615. [CrossRef] [PubMed]

66. Reid, M.S. Ethylene in plant growth, development, and senescence. In Plant Hormones; Davies, P.J., Ed.; Springer: Dordrecht, The Netherlands, 1995; pp. 486-508.

67. Hatami, M.; Hatamzadeh, A.; Ghasemnezhad, M.; Sajedi, R.H. Antioxidant enzymatic protection during pelargonium plant leaf senescence is mediated by thidiazuron. Trakia J. Sci. 2013, 11, 152-157.

68. Kaur, P.; Singh, K. Influence of growth regulators on physiology and senescence of cut stemsof Chrysanthemum (Chrysanthemum morifolium Ramat) Var. thai ching queen. IJAPPR 2015, 2, 31-41.

69. Aremu, A.O.; Bairu, M.W.; Szüčová, L.; Doležal, K.; Finnie, J.F.; van Staden, J. Assessment of the role of meta-topolins on in vitro produced phenolics and acclimatization competence of micropropagated “Williams" banana. Acta Physiol. Plant. 2012, 34, 2265-2273. [CrossRef]

70. Aremu, A.O.; Gruz, J.; Šubrtová, M.; Szüčová, L.; Doležal, K.; Bairu, M.W.; Finnie, J.F.; van Staden, J. Antioxidant and phenolic acid profiles of tissue cultured and acclimatized Merwilla plumbea plantlets in relation to the applied cytokinins. J. Plant Physiol. 2013, 170, 1303-1308. [CrossRef] [PubMed]

71. Pietta, P.-G. Flavonoids as Antioxidants. J. Nat. Prod. 2000, 63, 1035-1042. [CrossRef] [PubMed]

72. Shang, X.; He, X.; He, X.; Li, M.; Zhang, R.; Fan, P.; Zhang, Q.; Jia, Z. The genus Scutellaria an ethnopharmacological and phytochemical review. J. Ethnopharmacol. 2010, 128, 279-313. [CrossRef]

73. Alipieva, K.; Korkina, L.; Orhan, I.E.; Georgiev, M.I. Verbascoside-A review of its occurrence, (bio)synthesis and pharmacological significance. Biotechnol. Adv. 2014, 32, 1065-1076. [CrossRef]

74. Grzegorczyk-Karolak, I.; Rytczak, P.; Bielecki, S.; Wysokińska, H. The influence of liquid systems for shoot multiplication, secondary metabolite production and plant regeneration of Scutellaria alpina. Plant Cell Tissue Organ Cult. 2017, 128, 479-486. [CrossRef]

75. Grzegorczyk-Karolak, I.; Kuźma, Ł.; Wysokińska, H. The effect of cytokinins on shoot proliferation, secondary metabolite production and antioxidant potential in shoot cultures of Scutellaria alpina. Plant Cell Tissue Organ Cult. 2015, 122, 699-708. [CrossRef]

76. Grzegorczyk-Karolak, I.; Kuźma, Ł.; Wysokińska, H. Study on the chemical composition and antioxidant activity of extracts from shoot culture and regenerated plants of Scutellaria altissima L. Acta Physiol. Plant. 2015, 37, 1-9. [CrossRef] 
77. Aremu, A.O.; Stirk, W.A.; Masondo, N.A.; Plačková, L.; Novák, O.; Pěnčík, A.; Zatloukal, M.; Nisler, J.; Spíchal, L.; Doležal, K.; et al. Dissecting the role of two cytokinin analogues (INCYDE and PI-55) on in vitro organogenesis, phytohormone accumulation, phytochemical content and antioxidant activity. Plant Sci. 2015, 238, 81-94. [CrossRef] [PubMed]

78. Grúz, J.; Spíchal, L. Application of purine derivative LGR-1814 improves func- tional properties of field-grown lettuce (Lactuca sativa). In International PSE Symposium on Phytochemicals in Nutrition and Health; BARI: Giovinazzo, Italy, 2011; p. 30.

79. Coste, A.; Vlase, L.; Halmagyi, A.; Deliu, C.; Coldea, G. Effects of plant growth regulators and elicitors on production of secondary metabolites in shoot cultures of Hypericum hirsutum and Hypericum maculatum. Plant Cell Tissue Organ Cult. 2011, 106, 279-288. [CrossRef]

80. Kirakosyan, A.; Gibson, D.M.; Kaufman, P.B. The production of dianthrones and phloroglucinol derivatives in St. John's Wort. In Bioactive Molecules and Medicinal Plants; Ramawat, K., Merillon, J., Eds.; Springer: Berlin/Heidelberg, Germany, 2008; pp. 149-164.

81. Petrova, M.; Nikolova, M.; Zayova, E. Micropropagation and evaluation of flavonoid content and antioxidant activity of salvia. Genet. Plant Physiol. 2015, 5, 48-60.

82. De Moura, F.B.; Vieira, M.R.D.S.; Simoes, A.D.N.; Ferreira-Silva, S.L.; de Souza, C.A.; de Souza, E.S.; da Rocha, A.T.; da Silva, L.F.; Miguel, A. Physiological effect of kinetin on the photosynthetic apparatus and antioxidant enzymes activities during production of anthurium. Hortic. Plant J. 2018, 4, 182-192. [CrossRef]

83. Zhang, D.; Xu, X.; Zhang, Z.; Jiang, G.; Feng, L.; Duan, X.; Jiang, Y. 6-Benzylaminopurine improves the quality of harvested litchi fruit. Postharvest Biol. Technol. 2018, 143, 137-142. [CrossRef]

84. Wu, X.; Zhu, Z.; Li, X.; Zha, D. Effects of cytokinin on photosynthetic gas exchange, chlorophyll fluorescence parameters and antioxidative system in seedlings of eggplant (Solanum melongena L.) under salinity stress. Acta Physiol. Plant. 2012, 34, 2105-2114. [CrossRef]

85. Yang, D.Q.; Luo, Y.L.; Dong, W.H.; Yin, Y.P.; Li, Y.; Wang, Z.L. Response of photosystem II performance and antioxidant enzyme activities in stay-green wheat to cytokinin. Photosynthetica 2018, 56, 567-577. [CrossRef]

86. Liu, X.; Huang, B.; Banowetz, G. Cytokinin effects on creeping bentgrass responses to heat stress: I. Shoot and root growth. Crop Sci. 2002, 42, 457-465. [CrossRef]

87. Ren, B.; Zhang, J.; Dong, S.; Liu, P.; Zhao, B. Exogenous 6-benzyladenine improves antioxidative system and carbon metabolism of summer maize waterlogged in the field. J. Agron. Crop Sci. 2018, 204, 175-184. [CrossRef]

88. Hung, K.T.; Kao, C.H. Involvement of lipid peroxidation in water stress-promoted senescence of detached rice leaves. Plant Growth Regul. 1998, 24, 17-21. [CrossRef]

89. Xu, Y.; Huang, B. Effects of foliar-applied ethylene inhibitor and synthetic cytokinin on creeping bentgrass to enhance heat tolerance. Crop Sci. 2009, 49, 1876. [CrossRef]

90. Todorov, D.; Alexieva, V.; Karanov, E. Effect of putrescine, 4-PU-30, and abscisic acid on maize plants grown under normal, drought, and rewatering conditions. J. Plant Growth Regul. 1998, 17, 197-203. [CrossRef] [PubMed]

91. Ogweno, J.O.; Hu, W.H.; Song, X.S.; Shi, K.; Mao, W.H.; Zhou, Y.H.; Yu, J.Q. Photoinhibition-induced reduction in photosynthesis is alleviated by abscisic acid, cytokinin and brassinosteroid in detached tomato leaves. Plant Growth Regul. 2010, 60, 175-182. [CrossRef]

92. Ahanger, M.A.; Alyemeni, M.N.; Wijaya, L.; Alamri, S.A.; Alam, P.; Ashraf, M.; Ahmad, P. Potential of exogenously sourced kinetin in protecting Solanum lycopersicum from $\mathrm{NaCl}$-induced oxidative stress through up-regulation of the antioxidant system, ascorbate-glutathione cycle and glyoxalase system. PLoS ONE 2018, 13, e0202175. [CrossRef]

93. Zwack, P.J.; Rashotte, A.M. Interactions between cytokinin signalling and abiotic stress responses. J. Exp. Bot. 2015, 66, 4863-4871. [CrossRef] [PubMed]

94. Jameson, P.E. Cytokinins. In Encyclopedia of Applied Plant Sciences; Elsevier: Amsterdam, The Netherlands, 2017; Volume 1, pp. 391-402, ISBN 9780123948083.

95. Spallek, T.; Melnyk, C.W.; Wakatake, T.; Zhang, J.; Sakamoto, Y.; Kiba, T.; Yoshida, S.; Matsunaga, S.; Sakakibara, H.; Shirasu, K. Interspecies hormonal control of host root morphology by parasitic plants. Proc. Natl. Acad. Sci. USA 2017, 114, 5283-5288. [CrossRef] [PubMed] 
96. Sardesai, N.; Lee, L.; Chen, H.; Yi, H.; Olbricht, G.R.; Stimberg, A.; Jeffries, J.; Xiong, K.; Doerge, R.W.; Gelvin, S.B. Cytokinins secreted by Agrobacterium promote transformation by repressing a plant myb transcription factor. Sci. Signal. 2013, 6. [CrossRef] [PubMed]

97. Spallek, T.; Gan, P.; Kadota, Y.; Shirasu, K. Same tune, different song-Cytokinins as virulence factors in plant-pathogen interactions? Curr. Opin. Plant Biol. 2018, 44, 82-87. [CrossRef] [PubMed]

98. Savory, E.A.; Fuller, S.L.; Weisberg, A.J.; Thomas, W.J.; Gordon, M.I.; Stevens, D.M.; Creason, A.L.; Belcher, M.S.; Serdani, M.; Wiseman, M.S.; et al. Evolutionary transitions between beneficial and phytopathogenic Rhodococcus challenge disease management. Elife 2017, 6, 1-28. [CrossRef] [PubMed]

99. Stirk, W.A.; van Staden, J. Flow of cytokinins through the environment. Plant Growth Regul. 2010, 62, 101-116. [CrossRef]

100. Hinsch, J.; Galuszka, P.; Tudzynski, P. Functional characterization of the first filamentous fungal tRNA-isopentenyltransferase and its role in the virulence of Claviceps purpurea. New Phytol. 2016, 211, 980-992. [CrossRef] [PubMed]

101. Choi, J.; Huh, S.U.; Kojima, M.; Sakakibara, H.; Paek, K.H.; Hwang, I. The cytokinin-activated transcription factor ARR2 promotes plant immunity via TGA3/NPR1-dependent salicylic acid signaling in Arabidopsis. Dev. Cell 2010, 19, 284-295. [CrossRef] [PubMed]

102. Naseem, M.; Dandekar, T. The role of auxin-cytokinin antagonism in plant-pathogen interactions. PLoS Pathog. 2012, 8, e1003026. [CrossRef] [PubMed]

103. Walters, D.R.; McRoberts, N. Plants and biotrophs: A pivotal role for cytokinins? Trends Plant Sci. 2006, 11, 581-586. [CrossRef] [PubMed]

104. Chernyad'ev, I.I. Photosynthesis in sugar beet plants treated with benzyladenine and metribuzin during leaf ontogeny. Russ. J. Plant Physiol. 2000, 47, 161-167.

105. Chernyad'Ev, I.I. Ontogenetic changes in the photosynthetic apparatus and effects of cytokinins (review). Appl. Biochem. Microbiol. 2000, 36, 527-528. [CrossRef]

106. Stoynova, E.Z.; Iliev, L.K.; Georgiev, G.T. Structural and functional alterations in radish plants induced by the phenylurea cytokinin 4-PU-30. Biol. Plant. 1996, 38, 237-244. [CrossRef]

107. Tao, G.-Q.; Letham, D.S.; Yong, J.W.H.; Zhang, K.; John, P.C.L.; Schwartz, O.; Wong, S.C.; Farquhar, G.D. Promotion of shoot development and tuberisation in potato by expression of a chimaeric cytokinin synthesis gene at normal and elevated $\mathrm{CO}_{2}$ levels. Funct. Plant Biol. 2010, 37, 43. [CrossRef]

108. Kulaeva, O.N.; Burkhanova, E.A.; Karavaiko, N.N.; Selivankina, S.Y.; Porfirova, S.A.; Maslova, G.G.; Zemlyachenko, Y.V.; Börner, T. Chloroplasts affect the leaf response to cytokinin. J. Plant Physiol. 2002, 159, 1309-1316. [CrossRef]

109. Boasson, R.; Laetsch, W.M. Chloroplast replication and growth in tobacco. Science 1969, 166, 749-751. [CrossRef] [PubMed]

110. Harvey, B.M.R.; Lu, B.C.; Fletcher, R.A. Benzyladenine accelerates chloroplast differentiation and stimulates photosynthetic enzyme activity in cucumber cotyledons. Can. J. Bot. 1974, 52, 2581-2586. [CrossRef]

111. Momotani, E.; Aoki, K.; Tsuji, H. Effect of benzyladenine on diurnal changes in DNA content per chloroplast and chloroplast replication in intact bean leaves. J. Exp. Bot. 1991, 42, 1287-1293. [CrossRef]

112. Chory, J.; Reinecke, D.; Sim, S.; Washburn, T.; Brenner, M. A role for cytokinins in de-etiolation in Arabidopsis (det mutants have an altered response to cytokinins). Plant Physiol. 1994, 104, 339-347. [CrossRef]

113. Okazaki, K.; Kabeya, Y.; Suzuki, K.; Mori, T.; Ichikawa, T.; Matsui, M.; Nakanishi, H.; Miyagishima, S. The plastid division 1 and 2 components of the chloroplast division machinery determine the rate of chloroplast division in land plant cell differentiation. Plant Cell Online 2009, 21, 1769-1780. [CrossRef] [PubMed]

114. Sudriá, C.; Palazón, J.; Cusidó, R.; Bonfill, M.; Piñol, M.T.; Morales, C. Effect of benzyladenine and indolebutyric acid on ultrastructure, glands formation, and essential oil accumulation in Lavandula dentata plantlets. Biol. Plant. 2001, 44, 1-6. [CrossRef]

115. Kusnetsov, V.; Herrmann, R.G.; Kulaeva, O.N.; Oelmüller, R. Cytokinin stimulates and abscisic acid inhibits greening of etiolated Lupinus luteus cotyledons by affecting the expression of the light-sensitive protochlorophyllide oxidoreductase. Mol. Gen. Genet. 1998, 259, 21-28. [CrossRef]

116. Kuroda, H.; Masuda, T.; Fusada, N.; Ohta, H.; Takamiya, K.-I. Cytokinin-induced transcriptional activation of NADPH-protochlorophyllide oxidoreductase gene in cucumber. J. Plant Res. 2001, 114, 1-7. [CrossRef] 
117. Wilhelmova, N.; Kutik, J. Influence of exogenously applied 6-benzylaminopurine on the structure of chloroplasts and arrangement of their membranes. Photosynthetica 1995, 31, 559-570.

118. Zavaleta-Mancera, H.A.; Thomas, B.J.; Thomas, H.; Scott, I.M. Regreening of senescent nicotiana leaves. II. Redifferentiation of plastids. J. Exp. Bot. 1999, 50, 1683-1689. [CrossRef]

119. Zavaleta-Mancera, H.A.; Franklin, K.A.; Ougham, H.J.; Thomas, H.; Scott, I.M. Regreening of senescent Nicotiana leaves. I. Reappearance of NADPH-protochlorophyllide oxidoreductase and light-harvesting chlorophyll A/B-binding protein. J. Exp. Bot. 1999, 50, 1677-1682. [CrossRef]

120. Talla, S.K.; Panigrahy, M.; Kappara, S.; Nirosha, P.; Neelamraju, S.; Ramanan, R. Cytokinin delays dark-induced senescence in rice by maintaining the chlorophyll cycle and photosynthetic complexes. J. Exp. Bot. 2016, 67, 1839-1851. [CrossRef] [PubMed]

121. Paramonova, N.V.; Krasavina, M.S.; Sokolova, S.V. Ultrastructure of chloroplasts in phloem companion cells and mesophyll cells as related to the stimulation of sink activity by cytokinins. Russ. J. Plant Physiol. 2002, 49, 187-195. [CrossRef]

122. Synková, H.; Schnablová, R.; Polanská, L.; Hušák, M.; Šiffel, P.; Vácha, F.; Malbeck, J.; Macháčková, I.; Nebesářová, J. Three-dimensional reconstruction of anomalous chloroplasts in transgenic ipt tobacco. Planta 2006, 223, 659-671. [CrossRef] [PubMed]

123. Vlckova, A.; Spundova, M.; Kotabova, E.; Novotny, R.; Dolezal, K.; Naus, J. Protective cytokinin action switches to damaging during senescence of detached wheat leaves in continuous light. Physiol. Plant. 2006, 126, 257-267. [CrossRef]

124. Criado, M.V.; Caputo, C.; Roberts, I.N.; Castro, M.A.; Barneix, A.J. Cytokinin-induced changes of nitrogen remobilization and chloroplast ultrastructure in wheat (Triticum aestivum). J. Plant Physiol. 2009, 166, 1775-1785. [CrossRef]

125. Cortleven, A.; Schmülling, T. Regulation of chloroplast development and function by cytokinin. J. Exp. Bot. 2015, 66, 4999-5013. [CrossRef]

126. Lerbs, S.; Lerbs, W.; Klyachko, N.L.; Romanko, E.G.; Kulaeva, O.N.; Wollgiehn, R.; Parthier, B. Gene expression in cytokinin-and light-mediated plastogenesis of Cucurbita cotyledons: Ribulose-1,5-bisphosphate carboxylase/oxygenase. Planta 1984, 162, 289-298. [CrossRef]

127. Ohya, T.; Suzuki, H. The effects of benzyladenine on the accumulation of messenger RNAs that encode the large and small subunits of ribulose-1,5-bisphosphate carboxylase/oxygenase and light-harvesting chlorophyll A/B protein in excised cucumber cotyledons. Plant Cell Physiol. 1991, 32, 577-580. [CrossRef]

128. Benková, E.; Witters, E.; Van Dongen, W.; Kolar, J.; Motyka, V.; Brzobohatý, B.; van Onckelen, H.A.; Machácková, I. Cytokinins in tobacco and wheat chloroplasts. occurrence and changes due to light/dark treatment. Plant Physiol. 1999, 121, 245-252. [CrossRef]

129. Kasahara, H.; Takei, K.; Ueda, N.; Hishiyama, S.; Yamaya, T.; Kamiya, Y.; Yamaguchi, S.; Sakakibara, H. Distinct isoprenoid origins of cis-and trans-zeatin biosyntheses in Arabidopsis. J. Biol. Chem. 2004, 279, 14049-14054. [CrossRef] [PubMed]

130. Polanska, L.; Vicankova, A.; Novakova, M.; Malbeck, J.; Dobrev, P.I.; Brzobohaty, B.; Vankova, R.; Machackova, I. Altered cytokinin metabolism affects cytokinin, auxin, and abscisic acid contents in leaves and chloroplasts, and chloroplast ultrastructure in transgenic tobacco. J. Exp. Bot. 2007, 58, 637-649. [CrossRef]

131. Ananieva, K.; Malbeck, J.; Kaminek, M.; van Staden, J. Changes in endogenous cytokinin levels in cotyledons of Cucurbita pepo (zucchini) during natural and dark-induced senescence. Physiol. Plant. 2004, 122, 133-142. [CrossRef]

132. Ananieva, K.; Ananiev, E.D.; Doncheva, S.; Georgieva, K.; Tzvetkova, N.; Kamínek, M.; Motyka, V.; Dobrev, P.; Gajdošová, S.; Malbeck, J. Senescence progression in a single darkened cotyledon depends on the light status of the other cotyledon in Cucurbita pepo (zucchini) seedlings: Potential involvement of cytokinins and cytokinin oxidase/dehydrogenase activity. Physiol. Plant. 2008, 134, 609-623. [CrossRef]

133. Roberts, I.N.; Caputo, C.; Kade, M.; Criado, M.V.; Barneix, A.J. Subtilisin-like serine proteases involved in N remobilization during grain filling in wheat. Acta Physiol. Plant. 2011, 33, 1997-2001. [CrossRef]

134. Janečková, H.; Husičková, A.; Ferretti, U.; Prčina, M.; Pilařová, E.; Plačková, L.; Pospíšil, P.; Doležal, K.; Špundová, M. The interplay between cytokinins and light during senescence in detached Arabidopsis leaves. Plant. Cell Environ. 2018, 41, 1870-1885. [CrossRef] [PubMed] 
135. Wojciechowska, N.; Sobieszczuk-Nowicka, E.; Bagniewska-Zadworna, A. Plant organ senescenceRegulation by manifold pathways. Plant Biol. 2018, 20, 167-181. [CrossRef] [PubMed]

136. Weidhase, R.A.; Lehmann, J.; Kramell, H.; Sembdner, G.; Parthier, B. Degradation of ribulose-1,5bisphosphate carboxylase and chlorophyll in senescing barley leaf segments triggered by jasmonic acid methylester, and counteraction by cytokinin. Physiol. Plant. 1987, 69, 161-166. [CrossRef]

137. Selivankina, S.Y.; Karavaiko, N.N.; Kuiper, D.; Novikova, G.V.; Kulaeva, O.N. Cytokinin activity of zeatin allylic phosphate, a natural compound. Plant Growth Regul. 2001, 33, 157-164. [CrossRef]

138. Liu, X.; Huang, B. Cytokinin effects on creeping bentgrass response to heat stress. Crop Sci. 2002, $42,466$. [CrossRef]

139. Hudák, J.; Vizárová, G.; Šikulová, J.; Ovečková, O. Effect of cytokinins produced by strains of Agrobacterium tumefaciens with binary vectors on plastids in senescent barley leaves. Acta Physiol. Plant. 1996, 18, 205-210.

140. Catsky, J.; Pospisilova, J.; Kaminek, M.; Gaudinova, A.; Pulkrabek, J.; Zahradnicek, J. Seasonal changes in sugar beet photosynthesis as affected by exogenous cytokinin N6-(m-hydroxybenzyl)adenosine. Biol. Plant. 1996, 38, 511-518. [CrossRef]

141. Rivero, R.M.; Shulaev, V.; Blumwald, E. Cytokinin-dependent photorespiration and the protection of photosynthesis during water deficit. Plant Physiol. 2009, 150, 1530-1540. [CrossRef] [PubMed]

142. Zhang, Y.; Liang, C.Y.; Xu, Y.; Gianfagna, T.; Huang, B.R. Effects of Ipt gene expression on leaf senescence induced by nitrogen or phosphorus deficiency in creeping bentgrass. J. Am. Soc. Hortic. Sci. 2010, 135, 108-115.

143. Wang, K.; Zhang, X.; Ervin, E. Effects of nitrate and cytokinin on creeping bentgrass under supraoptimal temperatures. J. Plant Nutr. 2013, 36, 1549-1564. [CrossRef]

144. Weaver, L.M.; Gan, S.; Quirino, B.; Amasino, R.M. A comparison of the expression patterns of several senescence-associated genes in response to stress and hormone treatment. Plant Mol. Biol. 1998, 37, 455-469. [CrossRef] [PubMed]

145. Gepstein, S.; Sabehi, G.; Carp, M.-J.; Hajouj, T.; Nesher, M.F.O.; Yariv, I.; Dor, C.; Bassani, M. Large-scale identification of leaf senescence-associated genes. Plant J. 2003, 36, 629-642. [CrossRef]

146. Costa, M.L.; Civello, P.M.; Chaves, A.R.; Martínez, G.A. Effect of ethephon and 6-benzylaminopurine on chlorophyll degrading enzymes and a peroxidase-linked chlorophyll bleaching during post-harvest senescence of broccoli (Brassica oleracea L.) at $20^{\circ}$ C. Postharvest Biol. Technol. 2005, 35, 191-199. [CrossRef]

147. Sergiev, I.; Todorova, D.; Somleva, M.; Alexieva, V.; Karanov, E.; Stanoeva, E.; Lachkova, V.; Smith, A.; Hall, M. Influence of cytokinins and novel cytokinin antagonists on the senescence of detached leaves of Arabidopsis thaliana. Biol. Plant. 2007, 51, 377-380. [CrossRef]

148. Büchert, A.M.; Civello, P.M.; Martínez, G.A. Chlorophyllase versus pheophytinase as candidates for chlorophyll dephytilation during senescence of broccoli. J. Plant Physiol. 2011, 168, 337-343. [CrossRef]

149. Kuderová, A.; Gallová, L.; Kuricová, K.; Nejedlá, E.; Čurdová, A.; Micenková, L.; Plíhal, O.; Šmajs, D.; Spíchal, L.; Hejátko, J. Identification of AHK2- and AHK3-like cytokinin receptors in Brassica napus reveals two subfamilies of AHK2 orthologues. J. Exp. Bot. 2015, 66, 339-353. [CrossRef]

150. Lomin, S.N.; Krivosheev, D.M.; Steklov, M.Y.; Arkhipov, D.V.; Osolodkin, D.I.; Schmülling, T.; Romanov, G.A. Plant membrane assays with cytokinin receptors underpin the unique role of free cytokinin bases as biologically active ligands. J. Exp. Bot. 2015, 66, 1851-1863. [CrossRef]

151. Lomin, S.N.; Myakushina, Y.A.; Kolachevskaya, O.O.; Getman, I.A.; Arkhipov, D.V.; Savelieva, E.M.; Osolodkin, D.I.; Romanov, G.A. Cytokinin perception in potato: New features of canonical players. J. Exp. Bot. 2018, 69, 3839-3853. [CrossRef] [PubMed]

152. Halevy, A.H.; Dilley, D.R.; Wittwer, S.H. Senescence inhibition and respiration induced by growth retardants and 6N-benzyladenine. Plant Physiol. 1966, 41, 1085-1089. [CrossRef] [PubMed]

153. Adedipe, N.O.; Fletcher, R.A. Retardation of bean leaf senescence by benzyladenine and its influence on phosphate metabolism. Plant Physiol. 1970, 46, 614-617. [CrossRef] [PubMed]

154. Prokopová, J.; Špundová, M.; Sedlářová, M.; Husičková, A.; Novotný, R.; Doležal, K.; Nauš, J.; Lebeda, A. Photosynthetic responses of lettuce to downy mildew infection and cytokinin treatment. Plant Physiol. Biochem. 2010, 48, 716-723. [CrossRef]

155. Osborne, D.J. Effect of kinetin on protein \& nucleic acid metabolism in Xanthium leaves during senescence. Plant Physiol. 1962, 37, 595-602. [CrossRef] 
156. Von Abrams, G.J.; Pratt, H.K. Interaction of naphthaleneacetic acid and kinetin in the senescence of detached leaves. Plant Physiol. 1966, 41, 1525-1530. [CrossRef]

157. Kasamo, K. The role of the epidermis in kinetin-induced retardation of chlorophyll degradation in tobacco leaf discs during senescence. Plant Cell Physiol. 1976, 17, 1297-1307.

158. Zubo, Y.O.; Yamburenko, M.V.; Selivankina, S.Y.; Shakirova, F.M.; Avalbaev, A.M.; Kudryakova, N.V.; Zubkova, N.K.; Liere, K.; Kulaeva, O.N.; Kusnetsov, V.V.; et al. Cytokinin stimulates chloroplast transcription in detached barley leaves. Plant Physiol. 2008, 148, 1082-1093. [CrossRef]

159. Buschmann, C.; Lichtenthaler, H.K. The effect of cytokinins on growth and pigment accumulation of radish seedlings (Raphanus sativus L.) Grown in the dark and at different light quanta fluence rates. Photochem. Photobiol. 1982, 35, 217-221. [CrossRef]

160. Keshishian, E.A.; Rashotte, A.M. Plant cytokinin signalling. Essays Biochem. 2015, 58, 13-27. [CrossRef] [PubMed]

161. Brenner, W.G.; Ramireddy, E.; Heyl, A.; Schmülling, T. Gene regulation by cytokinin in Arabidopsis. Front. Plant Sci. 2012, 3, 1-22. [CrossRef] [PubMed]

162. Heyl, A.; Riefler, M.; Romanov, G.A.; Schmülling, T. Properties, functions and evolution of cytokinin receptors. Eur. J. Cell Biol. 2012, 91, 246-256. [CrossRef] [PubMed]

163. Inoue, T.; Higuchi, M.; Hashimoto, Y.; Seki, M.; Kobayashi, M.; Kato, T.; Tabata, S.; Shinozaki, K.; Kakimoto, T. Identification of CRE1 as a cytokinin receptor from Arabidopsis. Nature 2001, 409, 1060-1063. [CrossRef] [PubMed]

164. Brenner, W.G.; Schmulling, T. Summarizing and exploring data of a decade of cytokinin-related transcriptomics. Front. Plant Sci. 2015, 6, 1-13. [CrossRef] [PubMed]

165. Brandstatter, I.; Kieber, J.J. Two genes with similarity to bacterial response regulators are rapidly and specifically induced by cytokinin in Arabidopsis. Plant Cell Online 1998, 10, 1009-1020. [CrossRef]

166. Hwang, I.; Sheen, J. Two-component circuitry in Arabidopsis cytokinin signal transduction. Nature 2001, 413, 383-389. [CrossRef]

167. Zwack, P.J.; Robinson, B.R.; Risley, M.G.; Rashotte, A.M. Cytokinin response factor 6 negatively regulates leaf senescence and is induced in response to cytokinin and numerous abiotic stresses. Plant Cell Physiol. 2013, 54, 971-981. [CrossRef]

168. Cortleven, A.; Nitschke, S.; Klaumunzer, M.; AbdElgawad, H.; Asard, H.; Grimm, B.; Riefler, M.; Schmulling, T. A novel protective function for cytokinin in the light stress response is mediated by the Arabidopsis histidine kinase 2 and Arabidopsis histidine kinase 3 receptors. Plant Physiol. 2014, 164, 1470-1483. [CrossRef]

169. Cortleven, A.; Valcke, R. Evaluation of the photosynthetic activity in transgenic tobacco plants with altered endogenous cytokinin content: Lessons from cytokinin. Physiol. Plant. 2012, 144, 394-408. [CrossRef] [PubMed]

170. Gan, S.; Amasino, R.M. Making sense of senescence (molecular genetic regulation and manipulation of leaf senescence). Plant Physiol. 1997, 113, 313-319. [CrossRef] [PubMed]

171. Zwack, P.J.; Rashotte, A.M. Cytokinin inhibition of leaf senescence. Plant Signal. Behav. 2013, 8, e24737. [CrossRef] [PubMed]

172. Liu, M.-S.; Li, H.-C.; Lai, Y.-M.; Lo, H.-F.; Chen, L.-F.O. Proteomics and transcriptomics of broccoli subjected to exogenously supplied and transgenic senescence-induced cytokinin for amelioration of postharvest yellowing. J. Proteom. 2013, 93, 133-144. [CrossRef] [PubMed]

173. Chang, H.; Jones, M.L.; Banowetz, G.M.; Clark, D.G. Overproduction of cytokinins in petunia flowers transformed with P(SAG12)-IPT delays corolla senescence and decreases sensitivity to ethylene. Plant Physiol. 2003, 132, 2174-2183. [CrossRef] [PubMed]

174. Brady, C.J. Nucleic acid and protein synthesis. In Senescence and Aging in Plants; Noodén, L.D., Ed.; Academic Press: San Diego, CA, USA, 1988; pp. 147-178.

175. Taylor, C.B.; Bariola, P.A.; DelCardayre, S.B.; Raines, R.T.; Green, P.J. RNS2: A senescence-associated RNase of Arabidopsis that diverged from the S-RNases before speciation. Proc. Natl. Acad. Sci. USA 1993, 90, 5118-5122. [CrossRef] [PubMed]

176. Hensel, L.L.; Grbic, V.; Baumgarten, V.A.; Bleecker, A.B. Developmental and age-related processes that influence the longevity and senescence of photosynthetic tissues in Arabidopsis. Plant Cell 1993, 5, 553-564. [CrossRef] 
177. Lohman, K.N.; Gan, S.; John, M.C.; Amasino, R.M. Molecular analysis of natural leaf senescence in Arabidopsis thaliana. Physiol. Plant. 1994, 92, 322-328. [CrossRef]

178. Drake, R.; John, I.; Farrell, A.; Cooper, W.; Schuch, W.; Grierson, D. Isolation and analysis of cDNAs encoding tomato cysteine proteases expressed during leaf senescence. Plant Mol. Biol. 1996, 30, 755-767. [CrossRef]

179. Ryu, S.B.; Wang, X. Expression of phospholipase D during castor bean leaf senescence. Plant Physiol. 1995, 108, 713-719. [CrossRef]

180. Watanabe, A.; Hamada, K.; Yokoi, H.; Watanabe, A. Biphasic and differential expression of cytosolic glutamine synthetase genes of radish during seed germination and senescence of cotyledons. Plant Mol. Biol. 1994, 26, 1807-1817. [CrossRef] [PubMed]

181. Guo, Y.; Gan, S.S. Translational researches on leaf senescence for enhancing plant productivity and quality. J. Exp. Bot. 2014, 65, 3901-3913. [CrossRef] [PubMed]

182. Jordi, W.; Schapendonk, A.; Davelaar, E.; Stoopen, G.M.; Pot, C.S.; de Visser, R.; van Rhijn, J.A.; Gan, S.; Amasino, R.M. Increased cytokinin levels in transgenic P(SAG12)-IPT tobacco plants have large direct and indirect effects on leaf senescence, photosynthesis and N partitioning. Plant Cell Environ. 2000, 23, $279-289$. [CrossRef]

183. Lara, M.E.B.; Garcia, M.-C.G.; Fatima, T.; Ehneß, R.; Lee, T.K.; Proels, R.; Tanner, W.; Roitsch, T.; Lara, M.E.B.; Garcia, M.-C.G.; et al. Extracellular invertase is an essential component of cytokinin-mediated delay of senescence. Plant Cell 2004, 16, 1276-1287. [CrossRef] [PubMed]

184. Synková, H.; Semorádová, Š.; Schnablová, R.; Witters, E.; Hušák, M.; Valcke, R. Cytokinin-induced activity of antioxidant enzymes in transgenic Pssu-IPT tobacco during plant ontogeny. Biol. Plant. 2006, 50, 31-41. [CrossRef]

185. Dertinger, U.; Schaz, U.; Schulze, E.D. Age-dependence of the antioxidative system in tobacco with enhanced glutathione reductase activity or senescence-induced production of cytokinins. Physiol. Plant. 2003, 119, 19-29. [CrossRef]

186. Procházková, D.; Haisel, D.; Wilhelmová, N. Antioxidant protection during ageing and senescence in chloroplasts of tobacco with modulated life span. Cell Biochem. Funct. 2008, 26, 582-590. [CrossRef]

187. He, P.; Osaki, M.; Takebe, M.; Shinano, T.; Wasaki, J. Endogenous hormones and expression of senescence-related genes in different senescent types of maize. J. Exp. Bot. 2005, 56, 1117-1128. [CrossRef]

(C) 2018 by the authors. Licensee MDPI, Basel, Switzerland. This article is an open access article distributed under the terms and conditions of the Creative Commons Attribution (CC BY) license (http:/ / creativecommons.org/licenses/by/4.0/). 